Review

\title{
Promising bacterial genera for agricultural practices: An insight on plant growth-promoting properties and microbial safety aspects
}

\author{
Carlos M.H. Ferreira ${ }^{\mathrm{a}, \mathrm{b}, \mathrm{c}}$, Helena M.V.M. Soares ${ }^{\mathrm{a}}{ }_{*}$, Eduardo V. Soares ${ }^{\mathrm{b}, \mathrm{c}_{*}}{ }_{*}$ \\ a REQUIMTE/LAQV, Departamento de Engenharia Química, Faculdade de Engenharia, Universidade do Porto, rua Dr. Roberto Frias, $4200-465$ Porto, Portugal

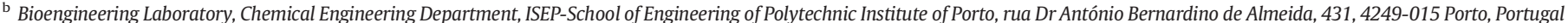 \\ c CEB-Centre of Biological Engineering, University of Minho, Campus de Gualtar, 4710-057 Braga, Portugal
}

\section{H I G H L I G H T S}

- The usefulness of bacteria for solving main agriculture problems is critically reviewed.

- Biosafety aspects linked with the use of PGPB in agriculture practices are discussed.

- An up to date overview of the main mechanisms associated with the use of PGPB is presented.

- The potentialities of several bacterial genera regarding their PGP properties are reviewed.

- Applied studies (field performance) of PGPB are presented.

\section{A R T I C L E I N F O}

\section{Article history:}

Received 22 February 2019

Received in revised form 12 April 2019

Accepted 15 April 2019

Available online 19 April 2019

Editor: Charlotte Poschenrieder

\section{Keywords:}

Biological fertilizers

Inhibition of phytopathogens

Iron-deficiency

Microbial siderophores

Plant growth promoting bacteria (PGPB)

Microbiological safety
G R A P H I C A L A B S T R A C T

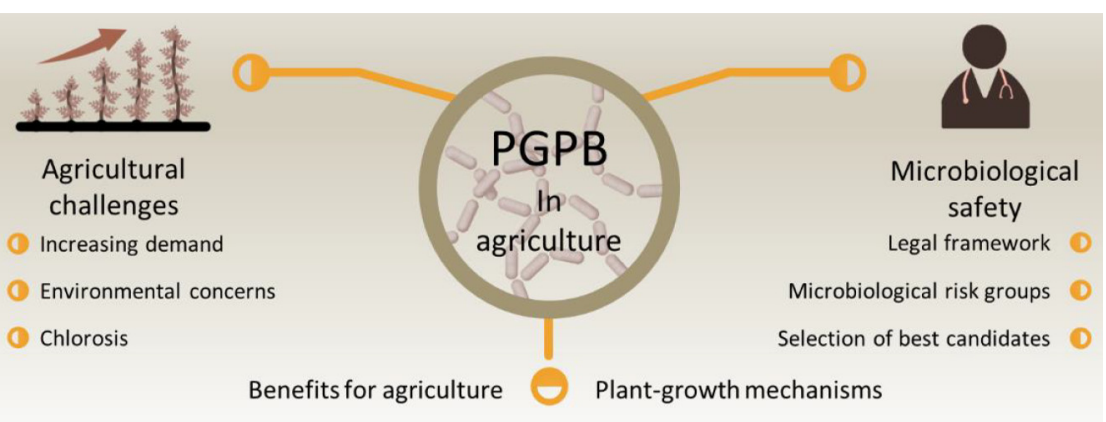

\begin{abstract}
A B S T R A C T
In order to address the ever-increasing problem of the world's population food needs, the optimization of farming crops yield, the combat of iron deficiency in plants (chlorosis) and the elimination/reduction of crop pathogens are of key challenges to solve. Traditional ways of solving these problems are either unpractical on a large scale (e.g. use of manure) or are not environmental friendly (e.g. application of iron-synthetic fertilizers or indiscriminate use of pesticides). Therefore, the search for greener substitutes, such as the application of siderophores of bacterial source or the use of plant-growth promoting bacteria (PGPB), is presented as a very promising alternative to enhance yield of crops and performance. However, the use of microorganisms is not a risk-free solution and the potential biohazards associated with the utilization of bacteria in agriculture should be considered. The present work gives a current overview of the main mechanisms associated with the use of bacteria in the promotion of plant growth. The potentiality of several bacterial genera (Azotobacter, Azospirillum, Bacillus, Pantoea, Pseudomonas and Rhizobium) regarding to siderophore production capacity and other plant growth-promoting properties are presented. In addition, the field performance of these bacteria genera as well as the biosafety aspects related with their use for agricultural proposes are reviewed and discussed.
\end{abstract}

c 2019 Published by Elsevier B.V.

\footnotetext{
* Corresponding authors.

E-mail addresses: hsoares@fe.up.pt (H.M.V.M. Soares), evs@isep.ipp.pt (E.V. Soares).
} 


\section{Contents}

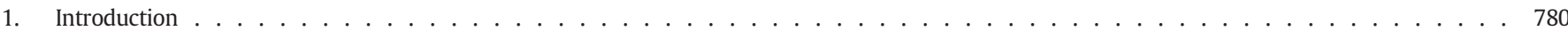

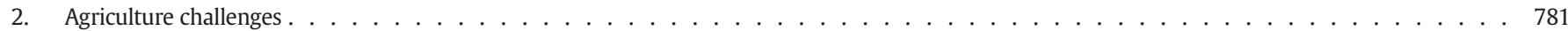

2.1. Chlorosis in plants: an increasing issue . . . . . . . . . . . . . . . . . . . . . . . . . . . . . . 781

2.1.1. Iron function in plants . . . . . . . . . . . . . . . . . . . . . . . . . . . . 781

2.1.2. Iron deficiency in plants: chlorosis . . . . . . . . . . . . . . . . . . . . . . . . . . . . 781

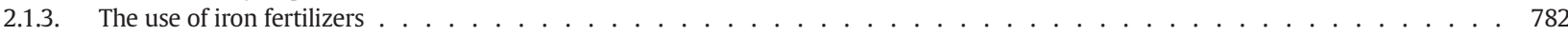

2.2. Pathogenic impairment on crops . . . . . . . . . . . . . . . . . . . . . . . . . . . . . . . . . . . . . . 782

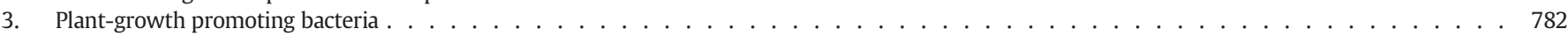

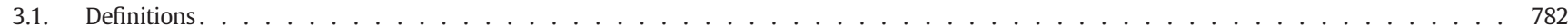

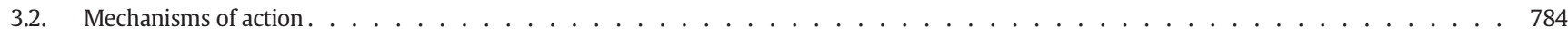

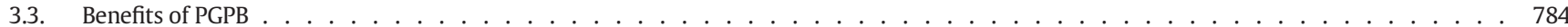

3.3.1. Macronutrients . . . . . . . . . . . . . . . . . . . . . . . . . . . . 784

3.3.2. Siderophores. . . . . . . . . . . . . . . . . . . . . . . . . . . . . . 785

3.3.3. Phytohormones and ACC deaminase . . . . . . . . . . . . . . . . . . . . . . . . . . . . . . . . . . . . 786

3.3.4. Pathogen antagonism. . . . . . . . . . . . . . . . . . . . . . . . . . . . 786

3.4. Microbiological safety. . . . . . . . . . . . . . . . . . . . . . . . . . . . . . . . . . .

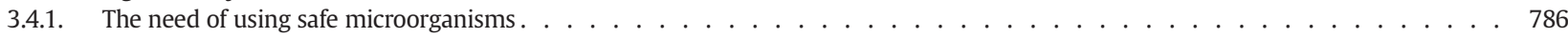

3.4.2. Biosafety classification . . . . . . . . . . . . . . . . . . . . . . . . . . . . . . . . . . 787

4. Promising bacterial genera for agricultural practices . . . . . . . . . . . . . . . . . . . . . . . . . . . . . 787

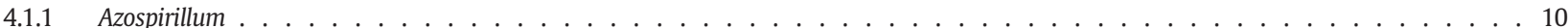

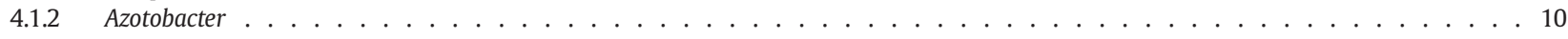

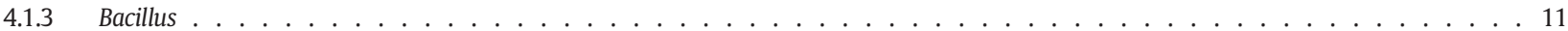

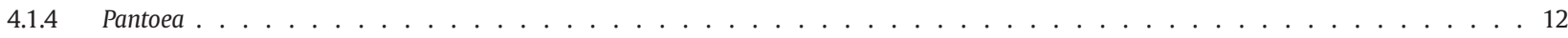

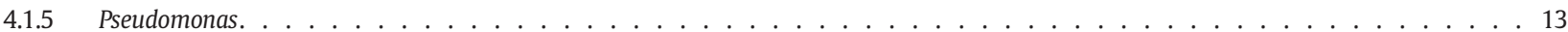

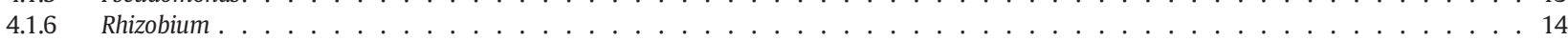

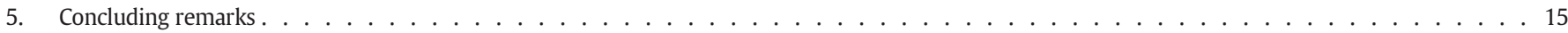

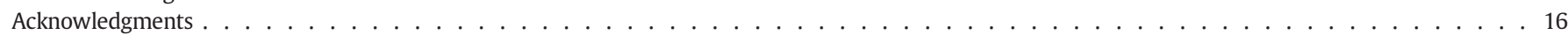

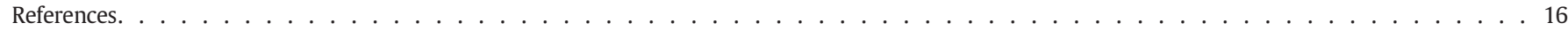

\section{Introduction}

World population is constantly increasing and currently there are around 7.7 billion people on planet Earth with current estimations placing a worldwide population of 10 billion by 2055 (Worldometers, 2018). This ever-increasing number puts Earth and its limited resources on stress. Arable fertile land is one of such resources (Alexander et al., 2017). As the population grows, more land is needed to supply enough food for all people. An alternative to avoid damaging progressively larger areas of wild land is to achieve increasing means of production.

A worldwide agricultural problem, with major implications in crop production, is the plant iron deficiency. Iron bioavailability is particularly low in calcareous soils (Hansen et al., 2006). Since it is estimated that calcareous soils cover about $30 \%$ of world's cultivated soils, plant iron deficiency arises as a major agricultural worldwide problem (Barker and Stratton, 2015; Hansen et al., 2006). The most common practice to overcome this problem is the application of synthetic iron chelates (Nadal et al., 2012), mostly aminopolycarboxylate acids (APCAs), such as ethylenediaminetetraacetic acid (EDTA) or ethylenediaminedi(ohydroxyphenylacetic) acid (EDDHA). Among APCAs, EDDHA/Fe(III) chelate is the most effective Fe fertilizer in neutral and alkaline soils (Alcañiz et al., 2017). In general, APACs are strong chelating agents; however, they usually are not biodegradable (Bucheli-Witschel and Egli, 2001). Consequently, their accumulation in the environment is becoming a matter of great concern (Bucheli-Witschel and Egli, 2001).

The search for better, cheaper, and more environmental-friendly alternative processes for increase food production or to solve specific agricultural problems (such as iron induced-chlorosis) is of utter importance and a major challenge. Such alternatives should, desirably, replace non-green or unsustainable practices, such as the intensive use of agrochemicals in field fertilization (chemical fertilization) or in the fight against phytopathogens (use of pesticides). The use of natural compounds, produced for instance by plant-growth promoting bacteria (PGPB), can be regarded as an alternative proposal for a more sustainable and environmental-friendly development of agricultural. Thus, it is not surprising the renewed and growing interest for PGPB (particularly in century XXI), which is translated into a huge number of published works (Fig. 1). Even, when the search in the Web of Science-Clarivate Analytics database is refined using the topics "siderophore production" and "bacteria" the same trend is observed (Fig. 1). Furthermore, the application of the Azospirillum genus has reached $>3.5$ million ha in South America in 2014, with a recorded average yield improvement of $10 \%$ (Cassán and Diaz-Zorita, 2016). The use of different microbial agents by foliar application or by seed inoculation was also reported to have positive effects on major crops, such as rice, wheat, sugar beet, corn, and cotton (Tabassum et al., 2017). It is forecast that PGPB market share will reach USD 1.66 billion by 2022 (Timmusk et al., 2017). Market ready mixes of bacteria and/or fungi exists, such as mixes of Bacillus amyloliquefaciens with Trichoderma virens or the combination of Trichoderma with Bradyrhizobium (Backer et al., 2018), and more PGPB based products are available commercially, as listed by Mustafa et al. (2019).

Different authors have reviewed the properties and traits of some PGPB (Bhattacharyya and Jha, 2012; Hayat et al., 2010; Tabassum et al., 2017), with focus on siderophore production/use (Ahmed and Holmström, 2014a; Gupta et al., 2018; Saha et al., 2013), biofertilization (Gupta et al., 2018) or bio-pesticide properties (Glick, 2010; Olanrewaju et al., 2017; Saraf et al., 2014). However, to our knowledge, no review addressed the environmental and public safety of bacteria for agricultural purposes.

The present work aimed to perform a comprehensive review of the potential application of bacteria, in sustainable agriculture, crossing, at the same time, relevant information regarding their safety. Thus, the most promising PGPB genera, for agronomic practices, are presented, in respect to their siderophore production capacity. In addition, examples of studies using these bacteria in the promotion of plant growth and biosafety aspects linked with their use in an agronomic context are critically reviewed. 

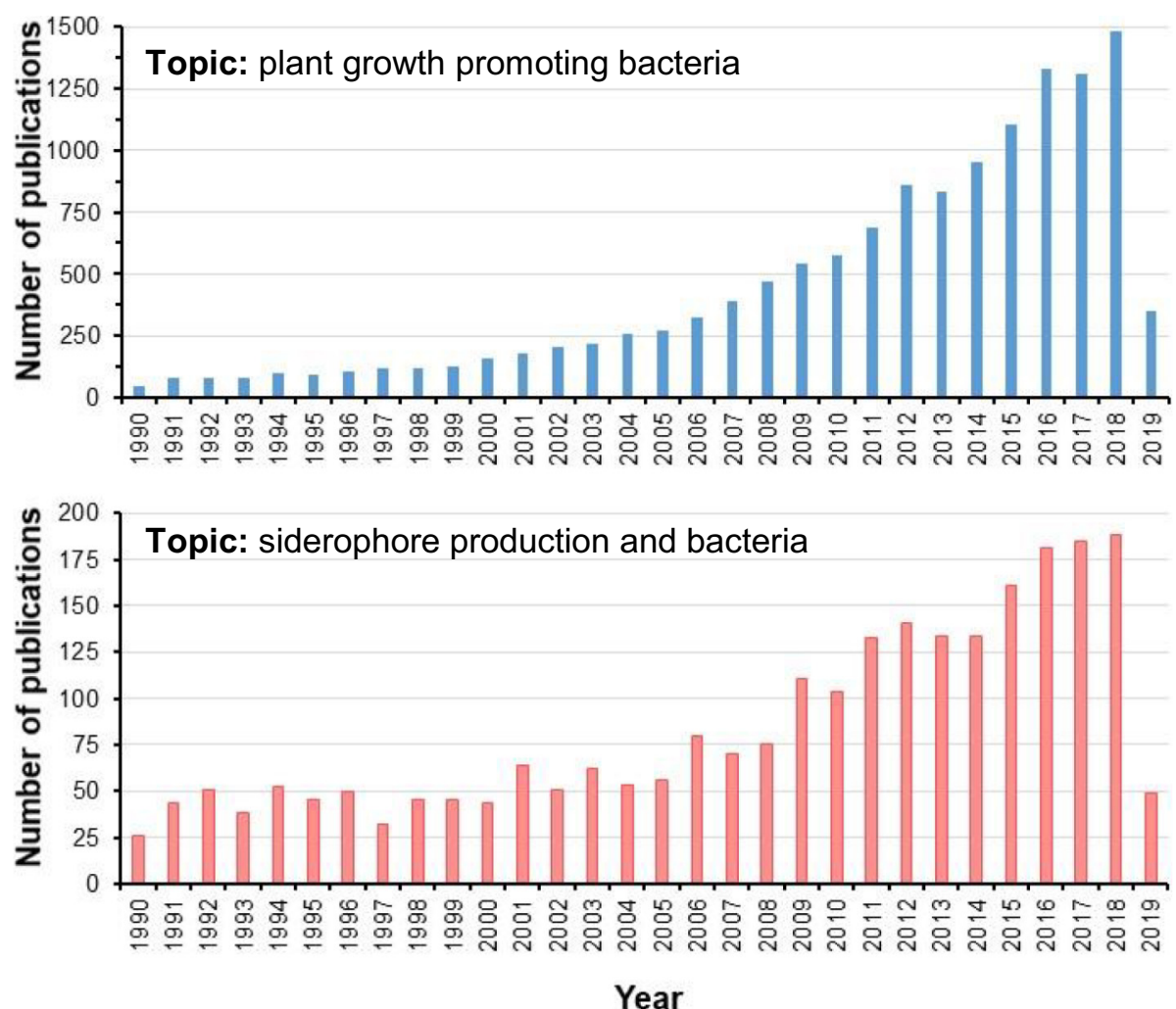

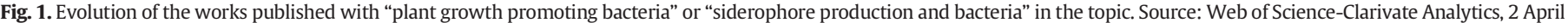
2019; search from 1990 to 2019.

\section{Agriculture challenges}

\subsection{Chlorosis in plants: an increasing issue}

\subsubsection{Iron function in plants}

It is generally recognized that iron is an essential micronutrient required in many plant processes, among which photosynthesis (Barker and Stratton, 2015). Although not present in chlorophylls, Fe is necessary for their synthesis and for the correct functioning of the photosynthetic apparatus as it is present in the three main complexes of the photosynthetic system: photosystem I, cytochrome $b_{6} f$ complex and photosystem II (Barker and Stratton, 2015; Briat et al., 2015; Broadley et al., 2012). In addition, non-heme Fe-S proteins (such as ferredoxin) and heme proteins, such as several enzymes (catalases and peroxidases) and cytochromes (which participate in the electron transport in photosynthesis, in chloroplasts, and in oxidative phosphorylation, in mitochondria) require the presence of iron to fulfill their functions in plant metabolism (Broadley et al., 2012). As a consequence, Fe is a key factor for proper plant biomass production and for high crop nutritional value (Briat et al., 2015). For a more detailed information about iron function in plants, the reader can consult the reviews performed by Broadley et al. (2012) and by Barker and Stratton (2015).

\subsubsection{Iron deficiency in plants: chlorosis}

The lack of iron in plants leads to a symptomatic array named iron deficiency induced chlorosis (IDIC), which is characterized by the appearance of yellow young leaves as a consequence of the inefficient chlorophyll production (Lucena, 2000). Plants under iron deficiency present chloroplasts with marked changes in their ultrastructure, being smaller under extreme iron deficiency (Broadley et al., 2012).

IDIC is a problem in agriculture as it can significantly reduce crop yields. Chlorotic plants will develop less, produce less biomass and yield less flowers and fruits, or even lead to complete crop failure (Guerinot and Yi, 1994). Some crops known to be susceptible to IDIC are peach, kiwifruit, citrus and pear (Lucena, 2003), but some other valuable crops have also been described to suffer from IDIC, such as rice, soybean, cotton, peanut (Hansen et al., 2006), tomato (Chaney et al., 2008) and pea (Kabir et al., 2016). Furthermore, Fe shortage leads to loss of nutrient value on harvested crops. For example, on developing countries, the major Fe source are vegetables (Barton and Abadia, 2006). Thus, Fe deficiency may hinder the production of proteins (Broadley et al., 2012), reducing the nutritional value of food. Therefore, insufficient Fe in crops may have detrimental effects on animal and human health. This further reinforces the need to solve the issue of Fe nutrition of plants, especially in susceptible crops.

The low bioavailability of iron is a result of its chemical nature and its low solubility and dissolution kinetics. Although Fe is generally present in high quantities in soil, in well drained soils most of Fe is found as crystalline Fe (hydro)oxides, such as goethite and hematite (Colombo et al., 2014). Under aerated conditions and pH values above 7, these ironminerals are highly insoluble and the free Fe concentration can be in the range of $10^{-10} \mathrm{~mol} \mathrm{~L}^{-1}$ (García-Marco et al., 2006), which is a value much lower than the required for the normal plant development $\left(\sim 10^{-7}\right.$ to $\left.10^{-8} \mathrm{~mol} \mathrm{~L}^{-1}\right)$ (Lindsay and Schwab, 1982). This is further aggravated if iron-minerals present a low surface area, especially in well crystalized minerals. This limits the absorption of iron by plants, especially in alkaline calcareous soils. In plants, the effects of bicarbonate on iron transport may also limit the distribution and availability of iron on leaves (Mengel, 1994). The presence of nitrates can also interfere with the $\mathrm{pH}$ and redox balance. Nitrate uptake system of plants is normally mediated by a proton cotransport system, which can increase local rhizosphere $\mathrm{pH}$. In strategy I plants, root reductases are speculated to reduce nitrate to nitrite in favor of $\mathrm{Fe}(\mathrm{III})$ to $\mathrm{Fe}$ (II), compromising Fe uptake by the root (Lucena, 2000). In strategy I plants (which corresponds to the most of non-graminaceous species), the reduction of Fe (III) to $\mathrm{Fe}(\mathrm{II})$ by a plasma membrane-bound reductase is an obligatory step prior to Fe intake via an iron regulated transporter (Barker and Stratton, 2015). Finally, heavy metals in soil can also disrupt the Fe 
Table 1

Factors affecting iron availability and uptake by plants.

\begin{tabular}{ll}
\hline Causes of low iron availability & Causes for low iron uptake by plants \\
\hline High pH, due to carbonates in soil & Bicarbonate buffering \\
$(\mathrm{pH}>7$ is critical) & \\
Types of minerals & Presence of nitrates affects $\mathrm{pH}$ and redox state \\
Low iron mineral surface & Presence and competition of heavy metals \\
\hline
\end{tabular}

uptake system on roots (Bashmakova et al., 2015). The main factors that influence the iron availability and uptake by plants are summarized in Table 1.

\subsubsection{The use of iron fertilizers}

2.1.3.1. Drawbacks of the use of inorganic and organic (synthetic) compounds. The challenge to overcome IDIC in agriculture and to increase crop yield has been of great importance and interest. The first response to the problem was the use of inorganic iron fertilizers, such as $\mathrm{FeSO}_{4}$ (Shenker and Chen, 2005). However, the supply of iron in this manner is inconsequent because iron readily precipitates due to the buffering capacity of carbonate/bicarbonates present in some soils (Lucena, 2003). Thus, organic chelating agents are more adequate for this purpose. While some organic acids, such as malic, citric and oxalic acids (Fig. 2), are suitable for foliar application or hydroponics (a method of growing plants using mineral nutrient aqueous solution instead of soil) where chlorosis is not severe, they are ineffective in providing Fe to plants in alkaline calcareous soils (Lucena, 2003). Another approach consists in the use of synthetic organic chelating agents, namely APCAs, which have high iron complex stability and are more adequate for soil application (Bucheli-Witschel and Egli, 2001). APCAs are compounds containing one or more nitrogen atoms to which carboxyl groups are linked (Fig. 2). Examples of synthetic APCAs are: diethylenetriaminepentaacetic acid (DTPA), EDDHA, ethylenediaminedi (o-hydroxy-p-methylphenylacetic) acid (EDDHMA), ethylenediaminedi (2-hydroxy-5-sulfophenylacetic) acid (EDDHSA), ethylenediaminedi(5carboxy-2-hydroxyphenylacetic) acid (EDDCHA), EDTA and N(hydroxyethyl)ethylenediaminetriacetic acid (HEDTA) (Fig. 2). The use of these compounds is regulated in the EU (European Union, 2003).

However, several issues arise from the use of such synthetic chelates in the agriculture. Firstly, the synthesis of EDDHA, which is one of the most commonly used synthetic chelating agents, originates a mixture of regioisomers: $o, o$-EDDHA, $o, p$-EDDHA, and $p, p$-EDDHA. The last two isomers have lower complexing capability and, therefore, reduces the value and efficiency of EDDHA as a iron fertilizer (HernándezApaolaza et al., 2006). Similar issues related to impurities in EDDHMA, EDDHSA and EDDCHA production were also found (AlvarezFernández et al., 2002). EDTA, although widely used in agriculture, has shown lower performances compared to EDDHA due to its lower chelating stability constants (Ferreira et al., 2019; López-Rayo et al., 2019). New APCA agents, such as $N, N^{\prime}$-bis(2-hydroxy-5-methylphenyl) ethylediamine- $N, N^{\prime}$-diacetic acid (HJB) (López-Rayo et al., 2009) or $N$, $N^{\prime}$-bis(2-hydroxybenzyl)ethylenediamine- $N, N^{\prime}$-diacetic acid (HBED) (Nadal et al., 2012) have been developed to cope with the issue of racemic mixtures of EDDHA and related chelating agents, since their synthesis yields purer compounds than the previous ones.

Another important problem associated with the extensive use of APCAs is related to their environmental impact. Synthetic APCAs are not biodegradable or poorly biodegradable (Bucheli-Witschel and Egli, 2001). For example, EDTA has been described as poorly biodegradable (Oviedo and Rodríguez, 2003), and its persistence and translocation in soil has been described (Bloem et al., 2017). As consequence of the limited biodegradability of APCAs, questions regarding its possible toxic effects on aquatic organisms and in mammalians, as a result of the mobilization of heavy metals, have been raised (Bucheli-Witschel and Egli, 2001).
2.1.3.2. Use of chelating compounds of biological origin as alternative. It is important to underline that a chelating agent must have some degree of persistence in soil in order to fulfill their function: efficient supply of iron for correcting chlorosis in plants. However, regarding to the biodegradability of the chelating agent, a balance should be achieved in order to avoid either an inefficient supply of iron (in the case of a fast biodegradability) or a possible toxic effect due to the leaching of metals (if not biodegradable).

In this context, new alternatives to synthetic APCAs should be sought in an attempt to find better candidates for being used as biodegradable iron fertilizers in agricultural practices. As possible candidates can be the APCAs of biological origin (natural occurring APCAs), such as ethylenediaminedisuccinate (EDDS), produced by Amycolatopsis orientalis or rhizobactin, produced by Rhizobium meliloti (Fig. 2) (Bucheli-Witschel and Egli, 2001). The latter compound is classified as siderophore (please see siderophore definition in Section 3.3.2.1), which present a better biodegradability comparing with the most synthetic APCAs (Fazary et al., 2016).

\subsection{Pathogenic impairment on crops}

As reported above, high crop yields are critical to meet the everincreasing demand on food. However, plant pathogens have a major impact on crop efficiency, quality and yield around the world. For example, it was estimated that $>484 \mathrm{M}$ bushels of soybeans were lost due to diseases in twenty eight U.S. states, during 2009 (Koenning and Wrather, 2010). Zymoseptoria tritici, a species of filamentous fungus, was responsible for wheat crop yield reductions with severe epidemics resulting in losses of up to $50 \%$; this pathogen was also responsible for the use of circa of $70 \%$ of the fungicides in the European Union (EU) (Fones and Gurr, 2015). Since their introduction in the 19th century, chemical fungicides, have been the main mean to fight and control fungi related plant diseases, with the consequent benefits to world's population feeding. Their use increased and by 2014 the world consumption of fungicides was of circa 14.7 billion US dollars (Maienfisch and Stevenson, 2015). However, the pressure on the discontinuation of fungicides is growing mainly due to: 1) considerable resistance to fungicides (Possiede et al., 2009); 2) fungicides and pesticides are generally considered concerning contaminants of water and soil causing environmental and health issues (Kaonga et al., 2017). These facts resulted on the decrease of the number of fungicides used in some countries (Zhang, 2018). For example, in Japan, recently, the trend of fungicide use has been declining (Kaonga et al., 2017). However, new developing economies may lead to a new surge in fungicide usage (Zhang, 2018).

Therefore, in addition to the need for further regulations on production, distribution and education for the use of pesticides, there is a need to: 1 ) develop of new, low toxic and highly efficient alternatives to combat plant pathogens; 2) minimize chemical pesticides and optimize the use of bio-pesticides. These points are of interest of this review and will be further addressed in following sections.

\section{Plant-growth promoting bacteria}

\subsection{Definitions}

Plant growth promoting bacteria (PGPB), consists in an large group of microorganisms that can be found in the rhizosphere (plant growth promoting rhizobacteria, PGPR), on the root surface or associated to it (Basu et al., 2017; Kloepper and Schroth, 1978). These bacteria live and interact with plants and improve plant growth (Basu et al., 2017; Chauhan et al., 2015; Gupta et al., 2018). Bacteria are indispensable part of this ecosystem and their presence is beneficial for plant growth (Bhattacharyya and Jha, 2012; Chauhan et al., 2015). Sometimes, plant roots, stimulate colonization of bacteria on the rhizosphere by exuding ions, free oxygen, water, enzymes, mucilage and a diverse carboncontaining primary and secondary metabolites, which can be used by 
<smiles>O=C(O)CC(O)(CC(=O)O)C(=O)O</smiles>

Citric acid<smiles>O=C(O)CCC(O)C(=O)O</smiles>

Malic acid<smiles>O=C(O)C(=O)O</smiles>

Oxalic acid

Natural organic chelating agents<smiles>O=C(O)CN(CCN(CC(=O)O)CC(=O)O)CCN(CC(=O)O)CC(=O)O</smiles><smiles>O=C(O)CN(CCN(CC(=O)O)CC(=O)O)CC(=O)O</smiles>

EDTA<smiles>O=C(O)CN(CCO)CCN(CC(=O)O)CC(=O)O</smiles>

HEDTA<smiles>O=C(O)c1ccc(O)c(C(NCCNC(C(=O)O)c2cc(C(=O)O)ccc2O)C(=O)O)c1</smiles><smiles>O=C(O)C(NCCNC(C(=O)O)c1ccccc1O)c1ccccc1O</smiles><smiles>Cc1ccc(C(NCCNC(C(=O)O)c2ccc(C)cc2O)C(=O)O)c(O)c1</smiles>

EDDHMA<smiles>O=C(O)C(NCCNC(C(=O)O)c1cc(S(=O)(=O)O)ccc1O)c1cc(S(=O)(=O)O)ccc1O</smiles>

EDDHSA

Synthetic aminopolycarboxylic acids<smiles>O=C(O)CCC(NCCCNC(CCC(=O)O)C(=O)O)C(=O)O</smiles><smiles>O=C(CC(O)C(=O)O)NCCCCC(NCCNC(O)C(=O)O)C(=O)O</smiles>

Rhizobactin 
bacteria (Dutta and Podile, 2010); therefore, the bacterial population may be as much as one thousand times more dense in the rhizosphere than in the bulk soil (Glick, 2014).

PGPR can be classified as: 1) extracellular-PGPR, which corresponds to bacteria mostly found on the rhizosphere or rhizoplane (surface of plant root that is in contact with soil) and more rarely on the spaces between root cortex and 2) intracellular-PGPR, which is related to bacteria found inside specialized nodules in roots (Jorquera et al., 2010). In more recent years, the PGPR classification was refined to include only species that satisfy two of the following three conditions: aggressive colonization, plant growth stimulation and biocontrol of pathogenic organisms (Bhattacharyya and Jha, 2012).

\subsection{Mechanisms of action}

The PGPB can exert their positive input on plant growth by different mechanisms, which can be classified by different ways. One possibility consists on the classification of the bacteria according to its function: biofertilizer, biostimulator or biocontrol (Fig. 3). Biofertilizers are mixtures of living microorganisms that when applied to seeds, plants or soil, promote the increase of nutrient supply, such as $\mathrm{NH}_{4}, \mathrm{SO}_{4}^{2-}$ or $\mathrm{PO}_{4}^{3-}$. A biostimulator is a microorganism with the ability to produce phytohormones, such as auxins (plant growth regulators with morphogen-like characteristics, like indole acetic acid, IAA) and cytokinins (substance that promote cell division). A biocontrol microorganism is that which promotes plant growth by controlling pathogenic populations, for instance, by producing antibiotics, hydrogen cyanide (HCN) or enzymes with the ability to hydrolyze the fungal cell wall (Bhattacharyya and Jha, 2012). The dissociation of HCN originate cyanide ion, which is a potent inhibitor of many metalloenzymes, particularly copper-containing cytochrome $c$ oxidases (Blumer and Haas,
2000). Therefore, the production of HCN by PGPB can originate an important reduction of phytopathogens and harmful rhizobacteria with the corresponding enhancement of plant health (Haas and Défago, 2005).

The mechanisms of action of PGPB can also be classified as being direct or indirect. Direct mechanisms consist on the supply of nutrients to the plant (either by nitrogen fixation or phosphate solubilization), increasing iron bioavailability (through siderophore production) as well as by production of phytohormones, like IAA (Fig. 3). Indirect mechanisms include antibiotic production, removal of phytotoxic substances, competition with pathogenic organism and stimulation of mycorrhizae (symbiotic association between fungus and plant roots) growth (Bhattacharyya and Jha, 2012).

\subsection{Benefits of $P G P B$}

\subsubsection{Macronutrients}

Plants need an array of elements/nutrients in greater quantity than others, namely carbon, which they obtain from the atmosphere. Plants also obtain other important macronutrients from the soil such as potassium, nitrogen, phosphorus or sulfur (Fig. 3). Regarding soil macronutrients, PGPB should, by definition, be capable of supplying host plants with additional nutrients or facilitate the acquisition of existing ones. Some bacteria are able to fix $\mathrm{N}_{2}$ (conversion of atmospheric nitrogen to ammonium) and supplying nitrogen to plants. Genera, such as Azotobacter (Kraepiel et al., 2009), Azospirillum (Steenhoudt and Vanderleyden, 2000), Azorhizobium and Rhizobium (Cocking, 2003), among others, are known to help plant growth by nitrogen fixation (Fig. 3). Within nitrogen-fixing bacteria some are free-living, i.e., do not require host to perform the process (such as: Azotobacter spp., Agrobacterium spp. and Azospirillum lipoferum) while others are

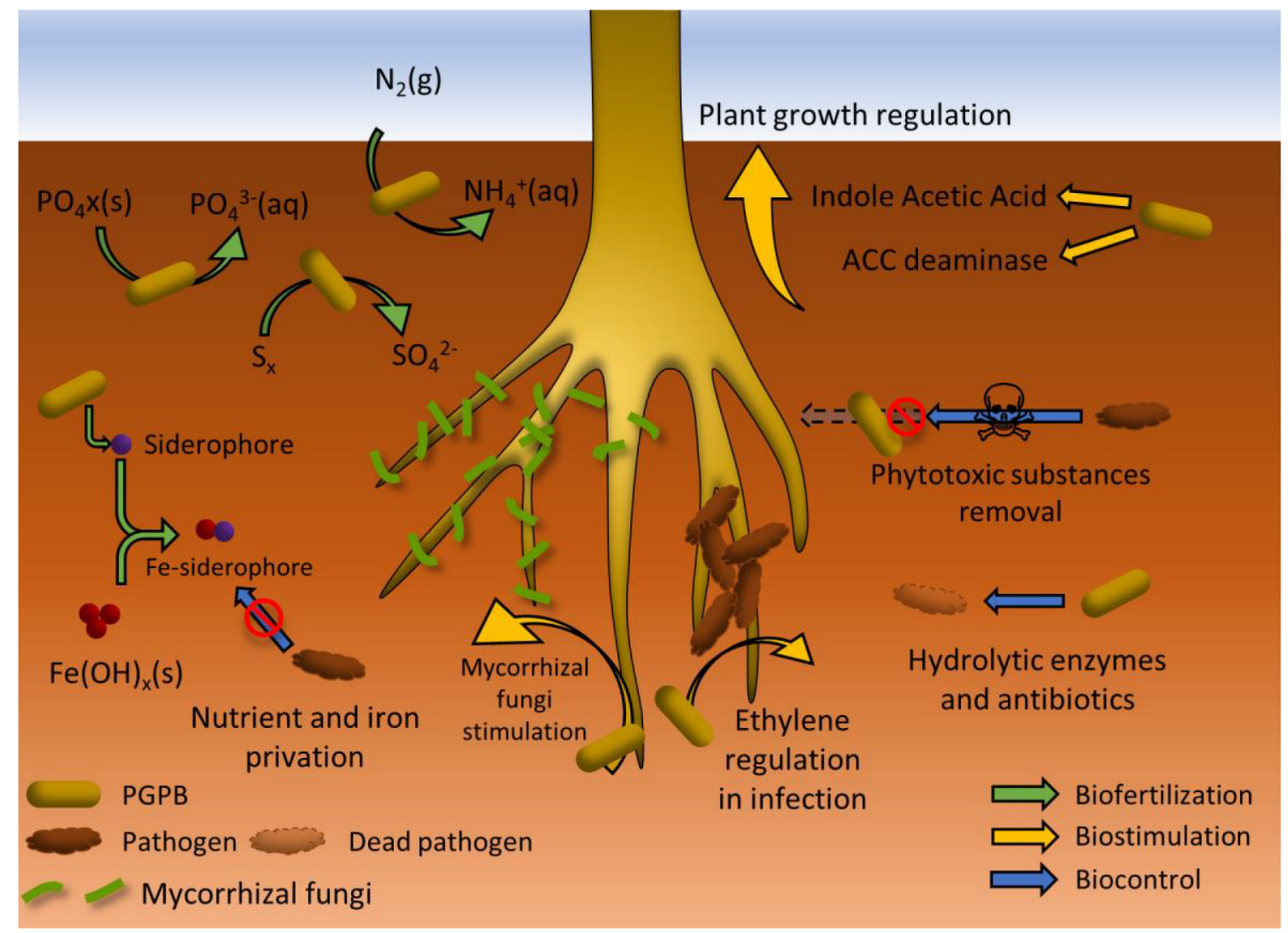

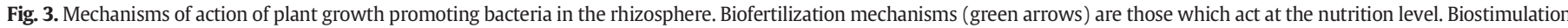

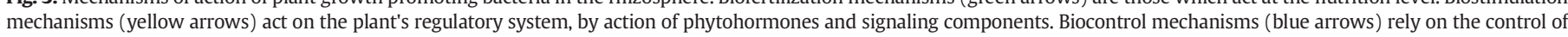
pathogenic microbial populations. (For interpretation of the references to colour in this figure legend, the reader is referred to the web version of this article.) 
symbiotic and only fix nitrogen in association with certain plants, such as leguminous (for example: Rhizobium spp. and Azorhizobium spp.) (Madigan and Martinko, 2006). PGPB comprises various rhizobia bacteria (such as Rhizobium and Bradyrhizobium) that grow free-living in the soil and infect the root cells of specific plants (legumes, such as soybeans) and leads to the formation of root nodules (Olanrewaju et al., 2017). Inside the plant cells, the rhizobia are transformed into swollen, misshapen forms named bacteroids; then, single or several bacteroids become enclosed by portions of the plant cell membrane to form the symbiosome (Madigan and Martinko, 2006). Only after the formation of the symbiosome, the bacteroids transform atmospheric nitrogen, through the enzyme nitrogenase, into ammonia. In return, plant supply organic acids (for bacteroids to produce energy) and provides an appropriate micro-environment for the action of nitrogenases, thus stablishing a symbiotic relationship between plant and bacterium (Madigan and Martinko, 2006; Olanrewaju et al., 2017).

Phosphorus is found in soil, as phosphates, but usually it is found in insoluble forms and, thus, not bioavailable for plants. Some bacteria have the ability of dissolving inorganic phosphates helping plants to cope their phosphorus needs (Fig. 3). Such bacteria comprise genera, such as Azotobacter (Kannapiran and Ramkumar, 2011), Burkholderia, Enterobacter, Serratia (Mamta et al., 2010) and Pantoea (Sulbarán et al., 2009). A major mechanism for phosphorus uptake in over $80 \%$ of plant species is through the symbiotic association between plant roots and fungi, known as mycorrhizae (Drinkwater et al., 2017). In plantmycorrhizal association, the fungi colonizes plant roots and obtain organic molecules from root secretions and get mineral nutrients, such as phosphate, obtained from the soil (Madigan and Martinko, 2006). The capacity of some PGPB, such as Streptomyces spp. or Rhizobium spp. to stimulate mycorrhizal fungi (Mycorrhiza Helper Bacteria) further contributes for a better phosphorous supply to plants (Baba et al., 2015; Franco-Correa et al., 2010).

Reduced inorganic sulfur compounds can be oxidized to sulfate by some bacteria genera like Aquaspirillum, Bacillus, Pseudomonas, Thiobacillus or Xanthobacter (Friedrich et al., 2001). This sulfate can be further absorbed by plants and promote their growth (Fig. 3).

Potassium is found in soils mainly in non-exchangeable mineral sources. Some Bacillus spp. are capable of dissolving potassium bearing minerals, constituting a supply of $\mathrm{K}$ to plants. These potassium solubilizing microorganisms and their mechanisms have been recently reviewed (Sattar et al., 2019).

\subsubsection{Siderophores}

3.3.2.1. Definition and function. Siderophores (from the greek sideros meaning iron and phores meaning bearer) are low weight molecules (between 500 and $1500 \mathrm{Da}$ ) that possess a great affinity and selectivity to bind and complex Fe(III) (Ahmed and Holmström, 2014a).

Siderophores are produced by microorganisms, such as bacteria and fungi, as well as by some graminaceous plants, as part of a strategy to obtain iron from the environment (Sah and Singh, 2015). As discussed above (iron deficiency in plants: chlorosis; Section 2.1.2), Fe(III) is very bio unavailable; in physiological conditions, the dissolved iron levels can be as low as $10^{-10} \mathrm{~mol} \cdot \mathrm{L}^{-1}$ (Kraemer, 2004). Microorganisms need an optimal Fe concentration of about $10^{-5}$ to $10^{-7} \mathrm{~mol} \cdot \mathrm{L}^{-1}$ (Saha et al., 2016) while for plants, some estimate place optimal Fe concentration at $10^{-9}$ to $10^{-4} \mathrm{~mol} \cdot \mathrm{L}^{-1}$ (Guerinot and Yi, 1994) while other authors estimate a value of $10^{-7}$ to $10^{-8} \mathrm{~mol} \cdot \mathrm{L}^{-1}$ (Lindsay and Schwab, 1982) for proper plant development.

3.3.2.2. Composition and structure. More than five hundred siderophores have been reported; among them, more than two hundred seventy have been structurally characterized (Barry and Challis, 2009). Despite this great variety, some common moieties are found among siderophores. These compounds usually have negatively charged oxygen atoms with high electron charge displaced [the higher the negative charge, the higher the affinity for Fe(III)]. In order to favor the more thermodynamically stable high-spin Fe(III) complexes, the most common geometry is octahedral with a six donor atoms arrangement and minimal ligand repulsion (Hider and Kong, 2010).

The most common moieties are oxygen bidentate, namely, catecholate, hydroxamate and carboxylate (Table 2). Others moieties exist, such as oxygen and nitrogen/oxygen-based, but are less frequent among microorganisms (Saha et al., 2016).

Besides the type of donor groups, side chains and complexation energies, other factors are equally important to define the stability strength of the complex. Among them, the denticity (number of donor groups in a single ligand that bind to the central atom) of the chelating agent is of paramount importance, as higher denticity results in a higher stability of the chelate formed (Hider and Kong, 2010). Then, in nature, it is expectable that the most common siderophores are hexadentate (six donor atoms) and can be found in linear or cyclic fashions (Hider and Kong, 2010). The pH is also a determinant factor on the kind of siderophores found. Usually, hydroxamates are more commonly found in neutral to acid environments while catecholates are more commonly found in neutral to alkaline environments (Saha et al., 2013).

Several bacterial genera were described to produce siderophores, such as Azotobacter (Baars et al., 2016; McRose et al., 2017; RomeroPerdomo et al., 2017), Azospirillum (Banik et al., 2016), Bacillus (Kesaulya et al., 2018; Pourbabaee et al., 2018), Dickeya (Sandy and Butler, 2011), Klebsiella (Bailey et al., 2018; Zhang et al., 2017), Nocardia (Hoshino et al., 2011), Pantoea (Burbank et al., 2015; Soutar and Stavrinides, 2018), Paenibacillus (Liu et al., 2017), Pseudomonas (Baune et al., 2017; Deori et al., 2018; Pourbabaee et al., 2018), Serratia (Coulthurst, 2014) and Streptomyces (Gáll et al., 2016; Goudjal et al., 2016; Schütze et al., 2014).

3.3.2.3. Stability and environmental fate. In the environment, the majority of siderophore producers are confined to plant rhizosphere (Chauhan et al., 2015). For this reason, the siderophore concentration is maximum in the rhizosphere zone, where concentrations as high as $0.1 \mu \mathrm{mol} \cdot \mathrm{L}^{-1}$ and $1 \mathrm{mmol} \cdot \mathrm{L}^{-1}$ for bacterial siderophore and plant phytosiderophore, respectively, were reported (Harrington et al., 2015). Conversely, siderophore concentration drops dramatically from rhizosphere to bulk soil, where siderophore concentrations can be as low as $10 \mathrm{nmol} \cdot \mathrm{L}^{-1}$ (Ahmed and Holmström, 2014b). However, these values may be underestimated due to sorption phenomena and inadequate extraction and detection protocols for siderophore quantification (Harrington et al., 2015). In fact, in soil, siderophores may adsorb to clay minerals (oxyhydr)oxides and organic matter (Powell et al., 1982). For example, the desferrioxamine B-Fe(III) complex has been shown to adsorb strongly with montmorillonite (Siebner-Freibach et al., 2006). However, this may be a positive aspect since the adsorbed $\mathrm{Fe}$ (III) complexes may be released over a greater period of time for plant usage (Ahmed and Holmström, 2014b). Similarly, it was demonstrated that desferrioxamine $\mathrm{B}$ adsorbs to iron-containing kaolinite and facilitates the dissolution of iron present on the clay-mineral (Rosenberg and Maurice, 2003).

In the environment, other fate for siderophores is its abiotic degradation, which may take place through hydrolyses and/or oxidation processes. The siderophores with hydroxamate moieties may suffer hydrolyses and generate hydroxylamine groups; this process is followed by the reduction of Fe(III) to Fe(II) (Simanova et al., 2010). Laboratory studies have shown that hydrolyze products from coprogen (tri-hydroxamate siderophore) were also effective iron-carriers to cucumber and maize plants (Hördt et al., 2000). All these facts evidence a possible strategy for siderophore utilization where the presence of "sacrificial" moieties may help on the reduction, dissolution and transport of iron to (micro)organisms (Harrington et al., 2015).

The exposure to sunlight has also influence on the mechanisms of siderophore degradation and mineral dissolution. The type of siderophore as well as the presence of chelated Fe, can induce different 
Table 2

Main moieties found in siderophores.

\begin{tabular}{l} 
Functional moiety \\
\hline Catecholate, catechol \\
Carboxylate \\
(If $\mathrm{R}_{1}=\mathrm{OH}$; $\alpha$-hydroxy-carboxylate)
\end{tabular}

behaviours. For example, hydroxycarboxylates, when complexed with iron are photo-reactive, while catecholates are only photo-reactive when not complexed; hydroxamates are not photo-reactive in both circumstances (Barbeau et al., 2003). The exposure to light also improves the rate of dissolution of some minerals by siderophores. Desferrioxamine B and aerobactin have been shown to dissolve lepidocrocite (an iron oxide-hydroxide mineral) faster when under UV-light exposure (Borer et al., 2009). Some other non-siderophore compounds carboxylates-containing, such as oxalate and malonate (and their $\alpha$-hydroxycarboxylate versions), have been shown to be photo-reactive when adsorbed into some iron minerals, such as hematite $\left(\mathrm{Fe}_{2} \mathrm{O}_{3}\right)$ or lepidocrocite, with possible dissolution of the minerals (Borer and Hug, 2014). Therefore, on its many forms, siderophore degradation, may have a positive influence on the iron uptake by organisms. This is due to the promotion of dissolution rates of mineral phases, iron reduction and transport to cells, while part of a dynamic environment of varied strategies for iron sequestration by organisms. As for their biotic fate, siderophores interact unavertable with (micro)organisms, being taken in by bacteria and plants (Bucheli-Witschel and Egli, 2001). It was also described the capacity of some bacteria to use siderophore as carbon and nitrogen source (Pierwola et al., 2004; Villa et al., 2014).

\subsubsection{Phytohormones and ACC deaminase}

The plant growth is controlled by phytohormones, namely auxins and ethylene, which control and model several aspects on plant, such as cell expansion and division, cell elongation and differentiation, and a variety of physiological responses (Jiang et al., 2017).

Among auxins, the most common is indole-3-acetic acid (IAA), which is known to be produced not only by plants but also by fungi and bacteria (Duca et al., 2014). Given its importance to the plant, there are several redundant tryptophan dependent metabolic pathways: the indole-3-pyruvic acid, indole-3-acetamide and indole-3-acetonitrile based pathways. These metabolic pathways have been described and reviewed elsewhere (Duca et al., 2014). Besides plants, some bacteria genera are also capable of producing IAA, such as Agrobacterium (Rashid et al., 2012; Sitbon et al., 1992), Azospirillum (Perrig et al., 2007), Azotobacter (Ahmad et al., 2008; Farajzadeh et al., 2012; Torres-Rubio et al., 2000), Bacillus (Ahmad et al., 2008; Mehta et al., 2010), Enterobacter (Shailesh et al., 2011; Viruel et al., 2011), Nocardia (Khamna et al., 2009), Pantoea (Shailesh et al., 2011; Viruel et al., 2011), Rhizobium (Shailesh et al., 2011; Tan et al., 2014), Serratia (Mamta et al., 2010), and Streptomyces (Gopalakrishnan et al., 2014). The IAA produced is part of the signaling and communication system between plants and bacteria present in the rhizosphere (Spaepen et al., 2007).

The correlation between IAA concentration and plant growth is not linear. Plants have an optimal endogenous IAA levels for their best development (Duca et al., 2014). Excess quantities of IAA may cause pathogenic effects on plants, such as the inhibition of root growth (Duca et al., 2014). Therefore, the use of IAA for plant stimulation has to be carefully regulated to avoid inhibitory effects from over dosage. In this context, plants possess neutralization mechanisms to control IAA excess, like inactivation of IAA by conjugation with sugars, amino acids or peptides (Sitbon et al., 1992).

Other important plant growth regulator is ethylene, which controls the growth of root, leaves, flowers and fruits (Dubois et al., 2018) as well as the interaction with microorganisms on roots (Gamalero et al., 2008). Ethylene is derived from 1-aminocyclopropane-1-carboxylate (ACC) and is produced in plants as response to multiple stresses (Dubois et al., 2018). Thus, different stresses, such as metals and chemicals, mechanical damage, water and temperature extremes, induce ethylene biosynthesis through the induction of ACC synthase (Dubois et al., 2018). When in excess, ethylene may be toxic to the plant causing defoliation and other harmful cellular effects (Desbrosses et al., 2009).

ACC deaminase (ACCD) is an enzyme produced by some bacteria, such as Azotobacter (Dubey et al., 2012; Farajzadeh et al., 2012), Bacillus (Belimov et al., 2001) and Pseudomonas (Kamran et al., 2016; Sandhya et al., 2010) and is considered as a key trait for PGPB strains (Glick, 2014). ACCD is beneficial for plants as it decreased ACC levels by cleaving it into ammonia and $\alpha$-ketobutyrate. This helps to regulate ethylene adverse effects by reducing its levels. Therefore, PGPB capable of producing ACCD are beneficial for plants grown in stress conditions such as drought (Sandhya et al., 2010), salt (Mayak et al., 2004) and heavy metals (Belimov et al., 2001) by regulating plant's ACC levels and, thus, of ethylene to non-toxic levels.

\subsubsection{Pathogen antagonism}

As an indirect method of plant growth promotion, antagonistic properties to plant pathogens are a valuable asset, as they can severely reduce or eliminate the incidence of plant diseases caused by fungi and bacteria. PGPB can achieve these effects by several mechanisms: production of hydrolytic enzymes; competition for nutrients; modulate ethylene levels caused by pathogenic infection; production of siderophores and antibiotics (Fig. 3) (Beneduzi et al., 2012). Several genera have been described as having antagonistic behavior to one or more plant pathogen, such as Bacillus (Heidarzadeh and BaghaeeRavari, 2015), Azospirillum (Tortora et al., 2011), Pseudomonas, Coniothyrium, Pythium (Woo and Lorito, 2007), Serratia, Burkholderia and Staphylococcus (Opelt et al., 2007). The use of these microorganisms has shown good results on improving plant growth over time when colonization of rhizosphere is successful (Backer et al., 2018; Mustafa et al., 2019; Tabassum et al., 2017).

\subsection{Microbiological safety}

\subsubsection{The need of using safe microorganisms}

One of the main problems when working with microorganism is their safety. In fact, the spread of microorganisms is a cause of concern, particularly when they are pathogenic to humans and/or to other organisms, such as animals and plants. Such considerations should also be taken into account when it is intended to use microorganisms for agricultural practices.

The use of microorganisms for agronomic proposes can fall in one of the two categories: 1 ) production of a compound (for instance, a fertilizer), that can be used in agriculture, by microbial fermentation or 2) bio-inoculants: the microorganisms (individual strains or microbial consortia) are added directly to the soil or as a seed coating when reseeding (Owen et al., 2015). In the first scenario, the organisms are confined to the place of production. However, production conditions and appropriate safety measures should be considered in order to reduce risks. The process, which includes the microbial cultivation and downstream processing (microbial harvesting, recovering and product processing), equipment and facilities should be designed in order to avoid or minimize the release of biological agents into work place. In addition, proper treatment and disposal of biological wastes should be taken into account as well as the training of the operators and the implementation of collective and individual protection measures. Even when working 
with biological agents with lowest risk, i.e., no or low individual and community risk, unlikely to cause human disease (group 1 biological agents; please see below), the procedures of good occupational safety and hygiene should be considered (European Union, 2000). According to EU directive (2000/54/EC), activities in which workers are (or are potentially) exposed to biological agents as a consequence of their work, the replacement of biological agents (that pose a risk to human health) for other microorganisms which pose no risk is mandatory, whenever possible (European Union, 2000). In the second case (bio-inoculants) the biological agent goes beyond the controlled area of the place of production. In this kind of application, it is very likely that the microorganisms will be set loose on the environment and may disrupt the natural microbial communities. For these reasons, the use of non-pathogenic microorganisms (to humans, animals and plants) is not only advisable but also desirable and even mandatory.

\subsubsection{Biosafety classification}

Organisms can be classified according to four risk-to-humans groups, as described in the Directive 2000/54/EC (European Union, 2000). Those biological agents unlikely to cause human disease are classified in group 1. If capable of causing disease and be a hazard to the workers, but no risk of spreading to the community, is classified in group 2; if can cause severe human disease or can spread to the community, is classified in group 3. In both these cases ( 2 and 3 ) there is usually effective prophylaxis or treatment available. If the biological agent causes severe human disease and is a serious hazard to workers and may present a high risk of spreading to the community and there is usually no effective prophylaxis or treatment available, then it is classified as group 4.
Besides the classification of biological agents taking into account the possible risks to humans, remarks can also be made on possible pathogenicity on vertebrates, invertebrates and plants (Committee on Biological Agents, 2015). The technical rules for biological Agents (TRBA)-466 (Committee on Biological Agents, 2015) are a well-suited tool for assessing the appropriateness of a given bacterium regarding its safety use in agricultural practices. For further crosscheck on risk groups of a given bacterium, the reader can consult the American Biological Safety Association site (https://my.absa.org/Riskgroups), which hosts most risk classifications for pathogenic species (although nonpathogenic species are not found there) or the Canadian Pathogen Safety Data Sheets (Public Health Agency of Canada, 2018).

Due to the reasons presented above, for agricultural purposes is desirable the use of microorganisms characterized as Risk 1 ; this requirement is absolutely necessary when biological agents are used directly applied in the soils.

\section{Promising bacterial genera for agricultural practices}

A thorough review of the literature was conducted for the bacteria genera with plant growth promotion (PGP) properties belonging mostly to risk 1 , which also have no or low phytotoxicity. In the following subsections, alphabetically, several genera of bacteria were reviewed taking into consideration the PGP attributes discussed above (namely, siderophore production, plant nutrient provision, biostimulation and biocontrol properties) and biosafety level (risk groups evaluation). It is also worthy to note that particular traits described in some genera may not be present in all species of the genera; similarly, some characteristics described may not be present in all strains belonging to a given species. For an exact information regarding the presence of a

Table 3

Main characteristics of promising bacterial genera for agricultural practices.

\begin{tabular}{|c|c|c|c|c|c|c|c|}
\hline \multirow[b]{2}{*}{ Genus } & \multicolumn{2}{|c|}{ General characteristics } & \multicolumn{2}{|l|}{ Siderophore } & \multicolumn{3}{|c|}{ Other agronomic characteristics } \\
\hline & Gram & Morphology & Name & Type & Biofertelization & Biostimulation & Biocontrol \\
\hline Azospirillum & Negative & Rod or spiral & $\begin{array}{c}\text { Spirilobactin } \\
\text { 2,3 - DHB } \\
\text { 3,5- DHB-threonine } \\
\text { 3,5 - DHB-lysine }\end{array}$ & $\begin{array}{l}\text { Catechol } \\
\text { Catechol } \\
\text { Catechol } \\
\text { Catechol }\end{array}$ & $\begin{array}{c}\text { Nitrogen fixation } \\
\text { Phosphate solubilization }\end{array}$ & $\begin{array}{c}\text { IAA } \\
\text { ACCD } \\
\text { GA } \\
\text { Kinetin } \\
\text { Abscisic acid } \\
\text { Zeatin }\end{array}$ & $\begin{array}{c}\text { HCN production } \\
\text { EPA: Colletotrichum acutatum }\end{array}$ \\
\hline Azotobacter & Negative & Spherical or ovoid & $\begin{array}{l}\text { 2,3 - DHB } \\
\text { Aminochelin } \\
\text { Azotochelin } \\
\text { Protochelin } \\
\text { Azotobactin } \\
\text { Vibrioferrin } \\
\text { 3,4 - DHB }\end{array}$ & $\begin{array}{l}\text { Catechol } \\
\text { Catechol } \\
\text { Catechol } \\
\text { Catechol } \\
\text { Mixed } \\
\text { Mixed } \\
\text { Chatecol }\end{array}$ & $\begin{array}{c}\text { Nitrogen fixation } \\
\text { Phosphate solubilization }\end{array}$ & $\begin{array}{c}\text { IAA } \\
\text { ACCD }\end{array}$ & $\begin{array}{c}\text { HCN production } \\
\text { EPA: Fusarium oxysporum } \\
\text { Rhizoctonia solani } \\
\text { Macrophomina phaseolina }\end{array}$ \\
\hline Bacillus & Positive & Rod & $\begin{array}{l}\text { Schizokinen } \\
\text { N- schizokinen } \\
\text { N-schizokinen-A } \\
\text { Itoic acid } \\
\text { Bacillobactin } \\
\text { Petrobactin }\end{array}$ & $\begin{array}{l}\text { Hydroxamate } \\
\text { Hydroxamate } \\
\text { Hydroxamate } \\
\text { Catechol } \\
\text { Catechol } \\
\text { Mixed }\end{array}$ & $\begin{array}{l}\text { Phosphate solubilization } \\
\text { Ammonia production }\end{array}$ & $\begin{array}{l}\text { IAA } \\
\text { ACCD } \\
\text { GA }\end{array}$ & $\begin{array}{c}\text { HCN production } \\
\text { EPA: Macrophomina phaseolina } \\
\text { Ralstonia solanacearum } \\
\text { Rhizoctonia solani } \\
\text { Fusarium oxysporum }\end{array}$ \\
\hline Pantoea & Negative & Rod & $\begin{array}{l}\text { Enterobactin-like } \\
\text { Desferrioxamine-like } \\
\text { Pyoverdine-like } \\
\text { Pyochelin-like }\end{array}$ & $\begin{array}{l}\text { Catechol } \\
\text { Hydroxamate } \\
\text { Mixed } \\
\text { Mixed }\end{array}$ & $\begin{array}{c}\text { Nitrogen fixation } \\
\text { Phosphate solubilization }\end{array}$ & $\begin{array}{c}\text { IAA } \\
\text { ACCD } \\
\text { GA } \\
\text { Cytokines } \\
\text { Abscisic acid }\end{array}$ & $\begin{array}{c}\text { EPA: Pseudomonas syringae } \\
\text { Erwinia amylovora }\end{array}$ \\
\hline Pseudomonas & Negative & Straight or slightly curved rods & $\begin{array}{c}\text { Pyochelin } \\
\text { Pseudobactin(s) } \\
\text { Pyoverdine(s) } \\
\text { Pyocyanin } \\
\text { Ferribactin } \\
\text { 7-hydroxytropolone }\end{array}$ & $\begin{array}{l}\text { Other } \\
\text { Mixed } \\
\text { Mixed } \\
\text { Other } \\
\text { Mixed } \\
\text { Other }\end{array}$ & $\begin{array}{c}\text { Nitrogen fixation } \\
\text { Ammonia production } \\
\text { Phosphate solubilization }\end{array}$ & $\begin{array}{c}\text { IAA } \\
\text { ACCD }\end{array}$ & $\begin{array}{l}\text { HCN production } \\
\text { EPA: Erwinia amylovora } \\
\text { Fusarium oxysporum } \\
\text { Fusarium udum } \\
\text { Pythium ultimum }\end{array}$ \\
\hline Rhizobium & Negative & Rod & $\begin{array}{l}\text { Agrobactin } \\
\text { Vicibactin } \\
\text { Schizokinen } \\
\text { 2,3 - DHB-threonine } \\
\text { Rhizobactin }\end{array}$ & $\begin{array}{l}\text { Catechol } \\
\text { Hydroxamate } \\
\text { Hydroxamate } \\
\text { Catechol } \\
\text { Catechol }\end{array}$ & $\begin{array}{c}\text { Nitrogen fixation } \\
\text { Phosphate solubilization }\end{array}$ & $\begin{array}{c}\text { IAA } \\
\text { ACCD }\end{array}$ & $\begin{array}{l}\text { EPA: Fusarium oxysporum } \\
\text { Rhizoctonia solani } \\
\text { Sclerotium rolfsii } \\
\text { Macrophomina phaseolina }\end{array}$ \\
\hline
\end{tabular}


specific characteristic in given genera, species or strain, the reader can consult the respective bibliographic references quoted.

\subsubsection{Azospirillum}

4.1.1.1. General genus description. The members of the genus Azospirillum are free living, but usually found colonizing plant roots, normally Gram negative, typically rod or spiral-shaped bacteria (Table 3 ). The species Azospirillum brasilense and Azospirillum lipoferum were first described (Lin et al., 2015). Subsequently, different species have been isolated and added to Azospirillum genus, such as Azospirillum amazonense (Cecagno et al., 2015) and Azospirillum melinis (Peng et al., 2006). Azospirillum genus is currently one of the most used PGPB as a result of its known properties for promoting the growth of several cereals, as it is the case of maize (Cassán and Diaz-Zorita, 2016).

4.1.1.2. Siderophore production. Azospirillum species are capable of producing siderophores. A catechol-type siderophore, named spirilobactin, was identified in iron-depleted medium of Azospirillum brasilense (Bachhawat and Ghosh, 1987). A strain of Azospirillum lipoferum, was described to produce 2,3-dihydroxybenzoic acid (2,3-DHBA) and 3,5DHBA conjugated with threonine and lysine (Shah et al., 1992), which are also responsible for siderophore-mediated Mo intake by Azospirillum lipoferum (Saxena et al., 1989). Others Azospirillum spp. have been described to produce siderophores (Banik et al., 2016; Sahoo et al., 2014).

4.1.1.3. Other PGP properties. Azospirillum spp. were reported to produce phytohormones, such as: IAA (Sahoo et al., 2014), kinetin (a type of cytokinin) (Tien et al., 1979), abscisic acid, zeatin (Perrig et al., 2007; Sahoo et al., 2014), ACCD, gibberellic acid (GA) (Sahoo et al., 2014). Azospirillum spp. are also able to fix nitrogen (Bellone et al., 2011; Gadagi et al., 2004), solubilize phosphate (Rodriguez et al., 2004) as well as producing HCN (Sahoo et al., 2014) and of having antagonistic properties toward some plant pathogens, such as Colletotrichum acutatum (Tortora et al., 2011).

4.1.1.4. Applied studies. Field studies with Azospirillum species yield, in a general way, good results (Fukami et al., 2016). For this reason, this genus has been received an increased attention. Banik et al. (2016) used new Azospirillum strains for improvement of rice production. Inoculation studies with Azospirillum spp. were conducted on wheat (Bashan et al., 1990; Noreen and Noreen, 2014), rice (García de Salamone et al., 2012) and soybean (Bashan et al., 1990). More recently, the interest in Azospirillum strains has increased due to positive results for plant growth enhancing in soils under osmotic stress (Fasciglione et al., 2015; García et al., 2017; Gonzalez et al., 2015).

4.1.1.5. Microbiological safety. All Azospirillum species belong to risk group 1 (Committee on Biological Agents, 2015). In addition, no adverse effects are predicted to plants, invertebrates or other non-human vertebrates, making Azospirillum a presumably safe and eco-friendly genus to use (Committee on Biological Agents, 2015). In fact, some studies have shown that the inoculation of soybean with Azospirillum brasilense did not affect native rhizobia population while increasing grain yield (Bellone et al., 2011).

\subsubsection{Azotobacter}

4.1.2.1. General genus description. The Azotobacter genus is characterized by spherical or ovoid Gram-negative bacteria (Table 3), usually motile, that can be found in soils, mostly in neutral or alkaline soils but also in aqueous medium and associated with plants (Voets and Dedeken, 1966). Azotobacter strains are also known to form resistant cysts during dormant phases or when exposed to some reagents (Diaz-Barrera and Soto, 2010). This genus is of great importance to the environment due to their great nitrogen fixation capacity, which is achieved as a consequence of the high metabolic rate of the three nitrogenases (McRose et al., 2017).

4.1.2.2. Siderophore production. Azotobacter vinelandii has the ability to produce several siderophores (Fig. 4). Azotobactin, initially called yellow-green fluorescent peptide, was isolated by Bulen and LeComte (1962). Latter, Corbin \& Bulen isolated 2,3-DHBA and azotochelin, produced by Azotobacter vinelandii under iron stress (Corbin and Bulen, 1969). In the meanwhile, the structure of azotobactin was characterized by Fukasawa et al. (1972); Fekete et al. (1983) concluded that all these three compounds are produced in iron depleted media and act as siderophores. Page and Tigerstrom (1988) isolated the monocatecholate aminochelin and, finally, in 1995, protochelin was isolated and characterized. This siderophore is a tri-catecholate, which is believed to be resultant of the condensation of aminochelin and azotochelin (Cornish and Page, 1995). The medium conditions for all siderophore production by Azotobacter vinelandii have been determined. In medium containing $\mathrm{Fe}(\mathrm{III})$ concentrations higher than 7 $\mu \mathrm{mol} \cdot \mathrm{L}^{-1}$, only 2,3 -DHBA is produced; when iron concentrations are below $7 \mu \mathrm{mol} \cdot \mathrm{L}^{-1}$, azotochelin and aminochelin are produced. If iron concentration in medium is under $3 \mu \mathrm{mol} \cdot \mathrm{L}^{-1}$, azotobactin is produced; finally, if iron is limited and Mo concentration is high $\left(>100 \mu \mathrm{mol} \cdot \mathrm{L}^{-1}\right)$, protochelin is produced (Duhme et al., 1998). More recently, in a broad genetic study on Azotobacter vinelandii, vibrioferrin was hinted, opening the possibility that one more siderophore is produced by Azotobacter vinelandii (Baars et al., 2016). Vibrioferrin was later described to be regulated by vanadium and molybdenum levels of culture medium (McRose et al., 2017).

In Azotobacter chroococcum strains, hydroxamate type siderophore production was described (Suneja et al., 1994), being dependent on the iron levels of the medium (Page, 1987). It was found an inverse relationship between nitrogen fixation and the (uncharacterized) siderophore production in Azotobacter chroococcum (Suneja et al., 1996). It was also found that ammonium citrate decreases the production of hydroxamate siderophores on Azotobacter chroococcum while boosting the production of catechol siderophores (Suneja et al., 1996).

Other Azotobacter species also produce siderophores (some of which were not yet characterized). For instance, Azotobacter paspali (reclassified as Azorhizophilus paspali) produces 3,4-dihydroxybenzoic acid (Collinson et al., 1987), Azotobacter salinestris produces hydroxamate type siderophores (Page and Shivprasad, 1995) and Azotobacter beijerinckii produces an unidentified siderophore type (Kannapiran and Ramkumar, 2011).

4.1.2.3. Other PGP properties. Some Azotobacter spp. have the capacity to fix nitrogen, solubilize phosphate, produce HCN, IAA (Ponmurugan et al., 2012) and ACCD (Sahoo et al., 2013). Azotobacter spp. were also reported as possible biocontrol agents against Fusarium oxysporum (Chauhan et al., 2012), Rhizoctonia solani (Fatima et al., 2009) or Macrophomina phaseolina (Dubey et al., 2012).

4.1.2.4. Applied studies. Due to their plant-growth promoting traits, Azotobacter spp. have been applied into plants to evaluate their capabilities to improve crop yields; examples are: cotton (Chauhan et al., 2012; Romero-Perdomo et al., 2017), sesame (Dubey et al., 2012), maize (Shirinbayan et al., 2019), wheat (Mahato and Kafle, 2018), rice (Sahoo et al., 2013), tomato (Chauhan et al., 2012), or maize (Shirinbayan et al., 2019). Growth improvement was measured through the increase to disease resistance (Chauhan et al., 2012; Dubey et al., 2012), plant biomass (Mahato and Kafle, 2018; Romero-Perdomo et al., 2017; Shirinbayan et al., 2019), nitrogen and Fe concentration (Shirinbayan et al., 2019), grain yield (Dubey et al., 2012; Mahato and Kafle, 2018) and drought resistance (Shirinbayan et al., 2019). 


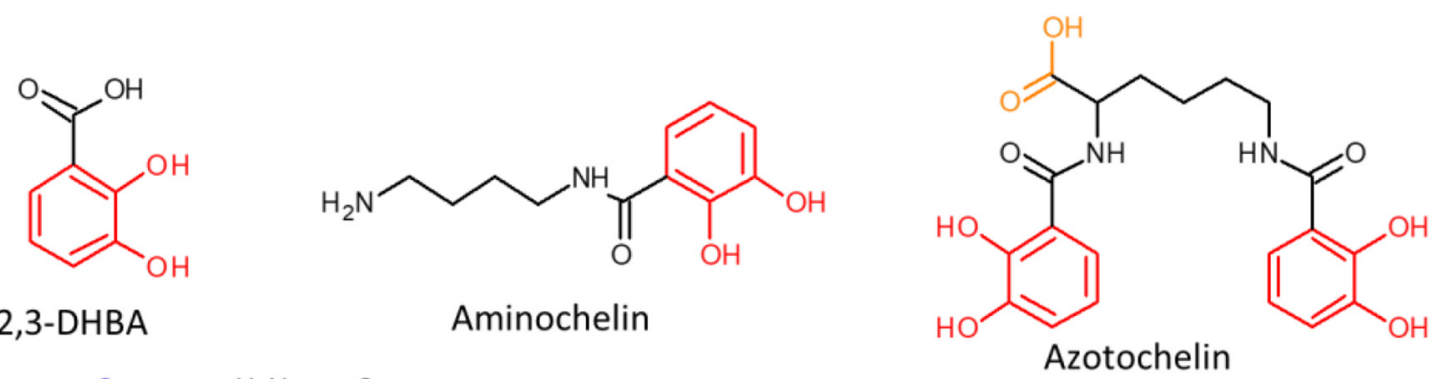<smiles>CC(=O)N(O)CCCC(NC(=O)C(CCO)NC(=O)C(CCCNC(N)=O)NC(=O)C(CO)NC(=O)C(NC(=O)CN)C(O)C(=O)O)C(=O)NC1CCOC1=O</smiles>

Azotochelin<smiles>O=C(NCCCCNC(=O)C(CCCCNC(=O)c1cccc(O)c1O)NC(=O)c1cccc(O)c1O)c1cccc(O)c1O</smiles><smiles>CC(C(=O)NCCOC(=O)CC(O)(CC(=O)O)C(=O)O)N1C(=O)CCC1(O)C(=O)O</smiles>

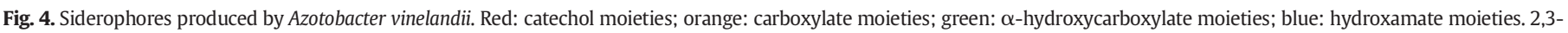
DHBA: 2,3-dihydroxybenzoic acid. (For interpretation of the references to colour in this figure legend, the reader is referred to the web version of this article.)

4.1.2.5. Microbiological safety. All the seven species registered on TRBA 466 are classified as risk group 1 (Committee on Biological Agents, 2015). Therefore, Azotobacter is a safe genus to be manipulated by humans. In addition, no indicated pathogeny to plants or other organisms was described (Committee on Biological Agents, 2015). Piromyou et al. (2013) have studied the effects of some PGPB inoculants (including Azotobacter spp.) in the microbial diversity and have concluded that the diversity indices were not different between the PGPBinoculated and un-inoculated.

\subsubsection{Bacillus}

4.1.3.1. General genus description. Bacillus genus is constituted by rod shaped, Gram-positive bacteria (Table 3), which can be either obligate aerobes or facultative aerobes, catalase positive and endospores producer (Turnbull, 1996). It is an omnipresent genus in nature, being found either in soil or water and even in extreme conditions, such as extremely alkaline (Bacillus alcalophilus) (Ntougias et al., 2006) or hot environments (Bacillus thermophilus) (Yang et al., 2013). Other known species from the genus are Bacillus subtilis, a model species broadly studied and described (Graumann, 2012), Bacillus anthracis, anthrax agent (Sheff, 2003), Bacillus thuringiensis, which is used as a natural insecticide (Sanchis and Bourguet, 2008) and Bacillus megaterium, which is among the biggest known bacteria; more recently, it became popular due to its recombinant protein production capacity (Bunk et al., 2010).

4.1.3.2. Siderophore production. It was described the ability of Bacillus megaterium to produce schizokinen, a di-hydroxamate, $\alpha$ hydroxycarboxylate siderophore (Fig. 5) (Byers et al., 1967). Later on, the ability of this bacterium to produce a deprotonated siderophore version ( $\mathrm{N}$ - schizokinen) and respective amine versions ( $\mathrm{N}$-schizokinen- $\mathrm{A}$ ) (Hu and Boyer, 1995) was also described. In this particular species, siderophore production is strongly correlated with carbon source in medium as well as with shaking and aeration conditions (Santos et al., 2014).

For Bacillus subtilis, the production of 2,3-dihydoxylbenzoylglycine, also known as itoic acid (Fig. 5), was described by Ito and Neilands (1958) in iron depleted conditions. Subsequently, the trimeric ester, named bacillibactin (Fig. 5) was described (May et al., 2001). The genes responsible for bacillibactin production have also been found in Bacillus amyloliquefaciens (Dunlap et al., 2013; Niazi et al., 2014). The production of bacillibactin was also reported in Bacillus anthracis, Bacillus cereus and Bacillus thuringiensis (Wilson et al., 2006). Petrobactin (Fig. 5), a di-catecholate and $\alpha$-hydroxycarboxylate siderophore, is synthetized by Bacillus anthracis (Koppisch et al., 2005) as well as by some strains of Bacillus thuringiensis (Koppisch et al., 2008), and probably by Bacillus cereus (Wilson et al., 2006).

4.1.3.3. Other PGP properties. Concerning to plant growth promotion characteristics, several works report different traits in Bacillus genus. The production of ACCD, IAA (Kumar et al., 2014), GA (Lenin and Jayanthi, 2012), ammonia (Ahmad et al., 2008) and the capacity to solubilize inorganic phosphates (Pourbabaee et al., 2018) by different $\mathrm{Ba}$ cillus has been reported. In addition the production of $\mathrm{HCN}$ (Pourbabaee et al., 2018) and biocontrol potential of Bacillus spp. against Macrophomina phaseolina (Kesaulya et al., 2018), Ralstonia solanacearum (Huang et al., 2016) or Rhizoctonia solani and Fusarium oxysporum (Kumar et al., 2014) was described. 


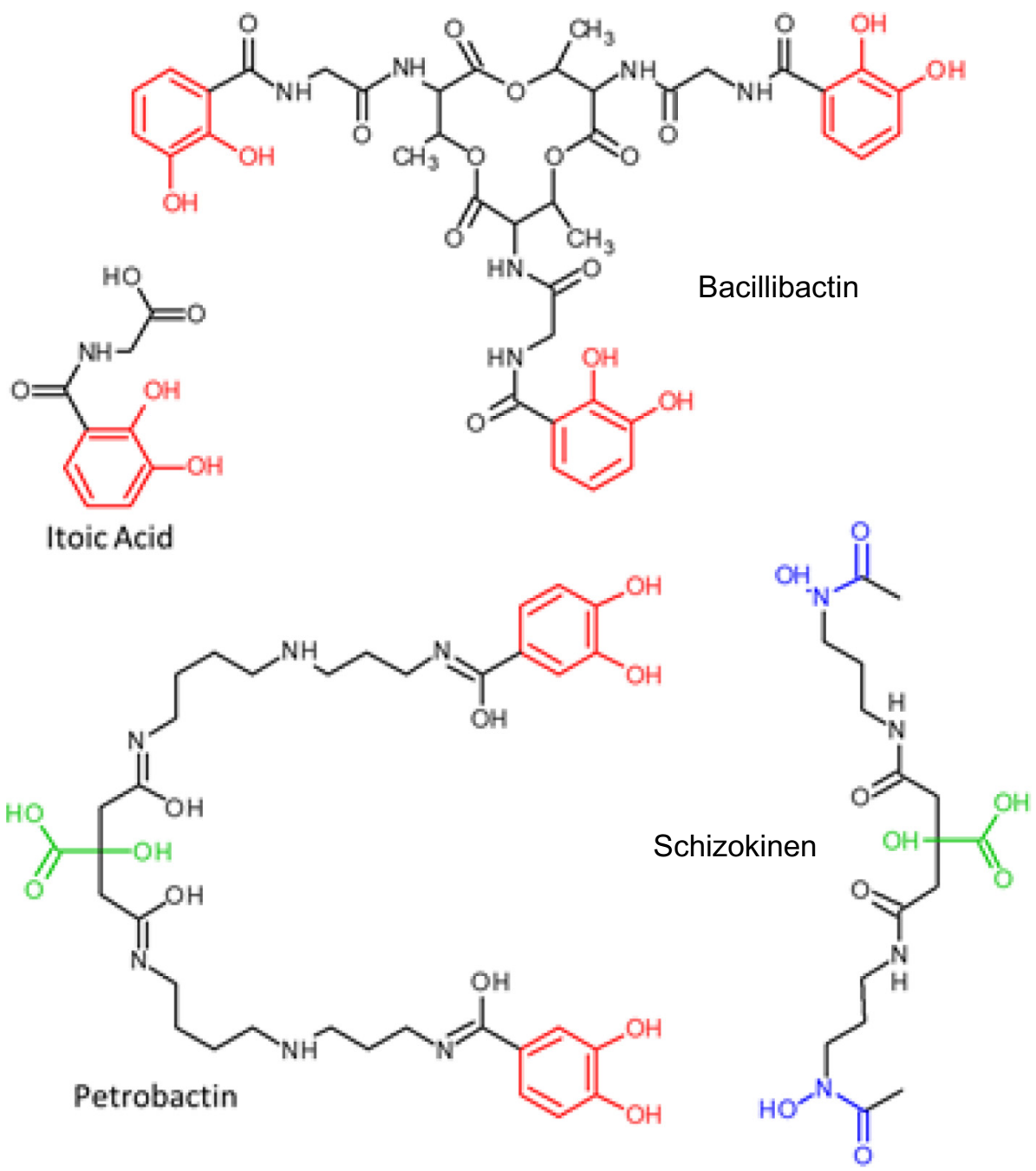

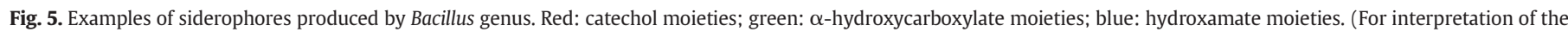
references to colour in this figure legend, the reader is referred to the web version of this article.)

4.1.3.4. Applied studies. Some authors applied Bacillus spp. to plants in order to test their effects on the plant/crop yield. For example, Bacillus spp. were applied to banana (Kesaulya et al., 2018), sunflower (Pourbabaee et al., 2018), bean (Sabaté et al., 2017), tobacco (Wu et al., 2016) and tomato (Akram et al., 2015; Heidarzadeh and Baghaee-Ravari, 2015) with positive outcomes, such as: increase of biomass (Akram et al., 2015; Pourbabaee et al., 2018; Sabaté et al., 2017), Fe and chlorophyll concentration (Pourbabaee et al., 2018) and resistance to pathogens (Kesaulya et al., 2018; Sabaté et al., 2017; Wu et al., 2016).

4.1.3.5. Microbiological safety. According to the TRBA 466, only three Bacillus species are not classified in risk group 1: Bacillus anthracis (risk group 3), Bacillus cereus and Bacillus weihenstephanensis (risk group 2) (Committee on Biological Agents, 2015). The most commonly found species (Bacillus subtilis, Bacillus megaterium, Bacillus amyloliquefaciens and Bacillus pumilus), belong to risk group 1. Bacillus thuringiensis is pathogenic to invertebrates and Bacillus cereus is a toxin producer but safe in technical conditions (Committee on Biological Agents, 2015).

Regarding the impact of Bacillus spp. inoculation on local rhizosphere populations, contradictory results have been reported. Felici et al. (2008) reported no changes on the rhizosphere communities after inoculation with Bacillus subtilis, whereas Probanza et al. (2002) have concluded that the introduction of two Bacillus (Bacillus licheniformis CECT 5106 and Bacillus pumilus CECT 5105) inoculants caused an alteration in the microbial rhizosphere composition. However, some changes in the microbial rhizosphere composition can be positive; for example, the application of Bacillus amyloliquefaciens ZM 9 affected positively the rhizosphere composition of tobacco plants by reducing pathogen populations ( $W u$ et al., 2016).

\subsubsection{Pantoea}

4.1.4.1. General genus description. The Pantoea genus, which has Pantoea agglomerans as type species, was recently separated from the Enterobacter genus. It is a motile Gram-negative rod shaped bacteria (Table 3), forming yellow mucoid colonies (Walterson and Stavrinides, 2015). Given to its versatility, ubiquity and genetic tractability, make it an ideal genus for the development of commercially relevant medical, agricultural and environmental bio products (Walterson and Stavrinides, 2015). Since the creation of the genus with Pantoea agglomerans, new species have strengthen the ranks of Pantoea genus, such as Pantoea allii (Brady et al., 2011), Pantoea vagans, Pantoea eucalypti, Pantoea deleyi and Pantoea anthophila (Brady et al., 2009).

4.1.4.2. Siderophore production. The production of siderophores was described for several Pantoea species, such as Pantoea agglomerans, Pantoea eucalyptii (Viruel et al., 2011), Pantoea allii (Pereira and Castro, 2014), Pantoea ananatis (Kim et al., 2012; Loaces et al., 2011), as well as for other Pantoea species (Loaces et al., 2011). However, little 
is known about these siderophores. The strain Pantoea vagans C9-1 is known to produce an enterobactin-like (catechol) siderophore and a desferrioxamine-like siderophore (Feistner and Ishimaru, 1996); the production of the latter compound is dependent on plasmatic transcription. Therefore, this characteristic is susceptible to be lost on some mutants (Smits et al., 2010). Pantoea stewartii subsp. stewartii produces a siderophore under iron-limiting conditions, which biosynthesis and export of proteins are encoded by the iucABCD-iutA operon; this operon is homologous to the aerobactin biosynthetic gene cluster found in a number of enteric pathogens (Burbank et al., 2015). It was also described that the strain Pantoea eucalypti M91 is capable of producing pyoverdine-like and pyochelin-like siderophores under alkaline growth conditions (Campestre et al., 2016). More recently, in a phylogenetic and comparative genomic study, desferrioxamine-like, enterobactinlike, and aerobactin-like siderophore biosynthetic gene clusters were found in several Pantoea strains (Soutar and Stavrinides, 2018). Judging from these findings, Pantoea strains are potentially capable of producing multiple and different types of siderophores.

4.1.4.3. Other PGP properties. The production of phytohormones, such as IAA, abscisic acid and GA (Feng et al., 2006) and cytokines (Omer et al., 2004) by different Pantoea spp. was reported. The production of ACCD was also described for Pantoea spp. strains (Trifi et al., 2017). In addition, nutrient based promoting traits, such as phosphate solubilization or nitrogen fixation (Kim et al., 2012) were described. The biocontrol potential of Pantoea spp. against Pseudomonas syringae (Xie et al., 2017) or Erwinia amylovora (Ait Bahadou et al., 2018) has also been reported.

4.1.4.4. Applied studies. The use of Pantoea spp. isolates for agronomic practices was tested in pot or field studies. Thus, the increased mass in plant bean (Gopalakrishnan et al., 2017), and in canola (Trifi et al., 2017), biocontrol action in mulberry seedlings (Xie et al., 2017), Fe intake in Lotus japonicus (Campestre et al., 2016), root development in olive trees (Montero-Calasanz et al., 2013), and increased crop yield and biomass in tomato, cucumber or pepper (Kim et al., 2012) was described.

4.1.4.5. Microbiological safety. Regarding safety aspects of working with Pantoea strains, from the twenty seven species listed on the TRBA-466, only four are not listed as risk group 1: Pantoea agglomerans, Pantoea brenneri, Pantoea eucrina and Pantoea septica (Committee on Biological Agents, 2015). Eleven species have been known as plant pathogens strains (Committee on Biological Agents, 2015). Despite this, the use of Pantoea strains, namely Pantoea agglomerans, at commercial level, as adjuncts to agricultural practice, has been reported (Glick, 2012). Pantoea allii, Pantoea ananatis and Pantoea vagans, which also have plant-growth properties, as reported above, are risk 1 species and can be possible species alternatives.

\subsubsection{Pseudomonas}

4.1.5.1. General genus description. The Pseudomonas genus is of medical and biotechnologically importance. It consists in aerobic, straight or slightly curved rods, Gram-negative bacteria (Table 3). Pseudomonas strains are found in biofilms or in planktonic forms with one or more polar flagella. Due to their high metabolic versatility, these bacteria are able of using most carbon sources (Özen and Ussery, 2012). The Pseudomonas genus is widely spread in the environment and some biotechnological important bacteria are inhabitants of a wide range of niches, such as soil and water environments, in addition to plant and animal associations (Özen and Ussery, 2012).

The Pseudomonas genus is one of the main PGPB genus that has received wide attention from the scientific community, being recognized for their biocontrol (Beneduzi et al., 2012) and agricultural potential (Bhattacharyya and Jha, 2012; Hayat et al., 2010).
4.1.5.2. Siderophore production. Several siderophores produced by Pseudomonas genus have been identified. Liu and Shokrani (1978) coined the term pyochelin to designate the large quantity of siderophores produced by Pseudomonas aeruginosa capable of harvesting iron from transferrin. The structural characterization of pyochelin (A) (Fig. 6) was latter made by Cox and co-workers (Cox et al., 1981; Cox and Graham, 1979). Meyer and Abdallah (1978) isolated and characterized the yellow-green, fluorescent, water-soluble pigment, produced by Pseudomonas fluorescens, suggesting that it was a siderophore. Kloepper et al. (1980) described the production of a siderophore in Pseudomonas strain B10. Later on, their colleagues characterized the structure of both pseudobactin (Fig. 6) and pseudobactin A (different in the quinoline derivatives) produced by Pseudomonas strain B10 (Teintze et al., 1981; Teintze and Leong, 1981). Pyoverdines are a large family of siderophores composed by a chromophore and a peptide chain (Fig. 6). The composition of this chain varies greatly from one pyoverdine to another and between different fluorescent Pseudomonas species (Ringel and Brüser, 2018). For example, three different pyoverdines, named, pyoverdine, pyoverdine ${ }_{0}$ and pyoverdine $A$ (as well as ferribactin), were isolated from Pseudomonas fluorescens (Philson and Llinas, 1982). The production of pyoverdines by Pseudomonas aeruginosa, such as pyoverdine $\mathrm{Pa}$, (Wendenbaum et al., 1983) and pyoverdine C, D and E (Briskot et al., 1986), as well as a blue pigment named pyocyanin (Cox, 1986), was also reported. Other Pseudomonas, such as Pseudomonas syringae, also produce pyoverdine type siderophores (Torres et al., 1986). Other example is Pseudomonas chlororaphis ATCC 9446 that produces pyoverdines and ferribactins similar to those produced by Pseudomonas fluorescens ATCC 13525 (Hohlneicher et al., 1995). Others authors described the production of hydroxamate siderophores by Pseudomonas fluorescens NCIM 5096 and Pseudomonas putida NCIM 2847 (Sayyed et al., 2005). The production of pyoverdine siderophores by Pseudomonas aureofaciens was also reported (Beiderbeck et al., 1999). In fact, given the wide production of siderophores by Pseudomonas spp., it has been proposed the use of siderophore typing as a form of identification of fluorescent and nonfluorescent Pseudomonas (Meyer et al., 2002, 1997). The importance, synthesis and variability of pyoverdines in Pseudomonas was also consequently reviewed (Visca et al., 2007). Some Pseudomonas have been described to produce non-fluorescent iron chelating compounds, such as 7-hydroxytropolone, which is produced in large quantities by Pseudomonas donghuensis (Jiang et al., 2016).

4.1.5.3. Other PGP properties. Other PGP characteristics had been extensively reported. The production of IAA and ACCD (Berta et al., 2014; Bona et al., 2015, 2017) by Pseudomonas spp. has been reported. In addition, HCN (Subramanian and Satyan, 2014) and ammonia production (Rashid et al., 2012; Subramanian and Satyan, 2014) as well as phosphate solubilization (Subramanian and Satyan, 2014) and nitrogen fixation (Pham et al., 2017) by Pseudomonas spp. was described. Antagonistic behavior on several plant pathogens, such as Erwinia amylovora (Ait Bahadou et al., 2018), Fusarium oxysporum (Deori et al., 2018) Pythium ultimum and Fusarium udum (Sulochana et al., 2014) was also described.

4.1.5.4. Applied studies. Given the described properties of Pseudomonas spp., this genus has been tested for their potential as agronomic inoculants. These studies have been conducted in crops such as sunflower (Pourbabaee et al., 2018), tomato (Nagata, 2017), chickpea (Gopalakrishnan et al., 2017; Sulochana et al., 2014), green gram (Kumar et al., 2015), wheat (Rasouli-Sadaghiani et al., 2014), rice (García de Salamone et al., 2012) or olive (Montero-Calasanz et al., 2013). Thus, it was reported the increase of Fe concentration (Nagata, 2017; Pourbabaee et al., 2018; Rasouli-Sadaghiani et al., 2014), (dry) plant mass (García de Salamone et al., 2012; Pourbabaee et al., 2018; Sulochana et al., 2014), resilience to drought (Pourbabaee et al., 2018), grain yield (García de Salamone et al., 2012; Gopalakrishnan et al., 
<smiles>CC(O)C1NC(=O)C(CCCN(O)C=O)NC(=O)C(NC(=O)C(CCCN(O)C=O)NC(=O)C(CO)NC(=O)C(CCCN=C(N)N)NC(=O)C(CO)NC(=O)C2CCNC3C(NC(=O)CCC(=O)O)=Cc4cc(O)c(O)cc4N23)CCCCNC(=O)C(C(C)O)NC1=O</smiles><smiles>CC(NC(=O)C(NC(=O)C(C)NC(=O)C(NC(=O)C(N)CCCCNC(=O)C1CCNc2c(NC(=O)CCC(N)=O)cc3cc(O)c(=O)cc-3n21)C(O)C(=O)O)C(C)O)C(=O)NC1CCCN(O)C1=O</smiles>

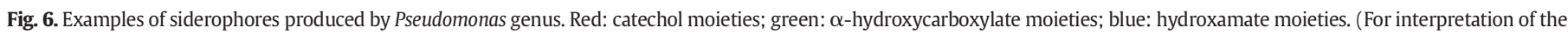
references to colour in this figure legend, the reader is referred to the web version of this article.)

2017), shoot length (Sulochana et al., 2014) or root length (MonteroCalasanz et al., 2013).

4.1.5.5. Microbiological safety. Regarding Pseudomonas spp. safety, a total of two hundred fifty five species (subspecies included) belonging to the group risk 1 were isolated (Committee on Biological Agents, 2015). However, some of the most mentioned species, as PGPB, are not risk 1, or, have other notes of pathogenicity in invertebrates/plants. For example, both Pseudomonas aeruginosa and Pseudomonas putida are risk 2 level, with known human and vertebrate pathogenic properties. However, there are some species that are not pathogenic and are suitable for safe application, with PGP traits. For instance, Pseudomonas fluorescens (a risk group 1 with only a remark for invertebrates) when inoculated in plants roots was reported as innocuous for the rhizosphere (De La Fuente et al., 2002). Also, the inoculation of Pseudomonas fluorescens in rice seems not impact, significantly, culturable microbial communities in rhizosphere (García de Salamone et al., 2012).

\subsubsection{Rhizobium}

4.1.6.1. General genus description. The Rhizobium genus includes Gramnegative rod shape bacteria (Table 3), usually mobile and able to use simple carbohydrates, predominantly aerobic chemoorganotrophs. Some species have shown to fix nitrogen while most of them do not fix it when they present as free living (Somasegaran and Hoben, 1994). Although not mandatory, they are also commonly found in the nodules of plant's roots; in this case, they are found as nitrogen fixators, forming symbiotic relations with the host plant (Lodwig et al., 2003). Rhizobium leguminosarum is the representative species of this evergrowing genus (Parte, 2018), which has $>90$ species registered on microorganisms banks, such as Deutsche Sammlung von Mikroorganismen und Zellkulturen.

Being symbionts with plants, it is predictable that Rhizobium species have traits that help the plants growth, as part of its symbiotic relation. In fact, not only Rhizobium species fixate nitrogen when in symbiosis with plants but they also produce other compounds, such as siderophores, phytohormones and other growth regulators.

4.1.6.2. Siderophore production. Several siderophores have been described to be produced by Rhizobium spp. Rhizobium radiobacter (then known as Agrobacterium tumefaciens and later as Agrobacterium radiobacter) was shown to produce a tri-catecholate siderophore named agrobactin (Fig. 7) (Eng-Wilmot and Van der Helm, 1980; Ong et al., 1979). Some strains of Rhizobium radiobacter were also able to produce hydroxamate type siderophores (Leong and Neilands, 1982). Smith and Neilands (1984) reported that Rhizobium meliloti produces a non-catecholate and a non-hydroxamate siderophore named rhizobactin (Fig. 2); later on, these authors have been working on its structure and described it as a di $\alpha$-hydroxy-carboxylate siderophore (Smith et al., 1985). Rhizobium meliloti 1021 strain (also known as Sinorhizobium meliloti or Ensifer meliloti) was found to produce a variant of rhizobactin, named rhizobactin 1021 (Persmark et al., 1993). Rhizobium leguminosarum IARI 102 produced 2,3-DHBA conjugated with threonine (2,3-DHBA-Thr) (Fig. 7), under iron starved conditions. On the other hand, the Rhizobium leguminosarum IARI 917 strain was described to produce the schizokinen siderophore (Fig. 5) (Storey et al., 2006). Rhizobium leguminosarum ATCC 14479 was described to produce vicibactin (Fig. 7), a try-hydroxamate, and two other iron-binding siderophore-like compounds (Wright et al., 2013). It can then be concluded that Rhizobium genus has the ability to produce several siderophores, which can be tapped for possible uses in agricultural, medical and engineering purposes.

4.1.6.3. Other PGP properties. The production of ACCD and IAA has been described in Rhizobium spp. (Hernández et al., 2017). Rhizobium spp. has also the ability to solubilize phosphate (Kumar et al., 2015; Xing et al., 2016) and to fix atmospheric nitrogen when in root nodules (Datta et al., 2015). The antagonistic activity against different plant pathogens, such as Fusarium oxysporum (Arfaoui et al., 2006), Rhizoctonia solani, Sclerotium rolfsii (Sai Prasad et al., 2014) Macrophomina 


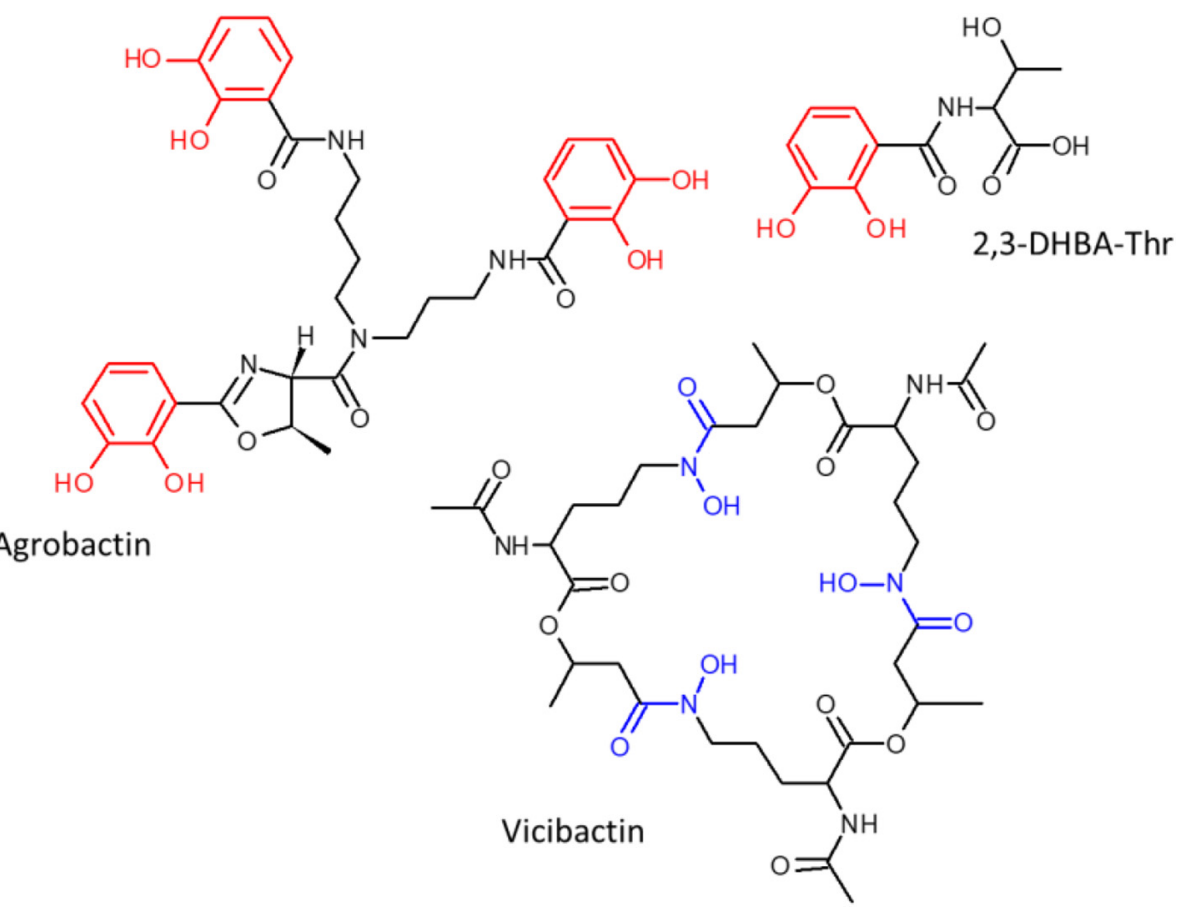

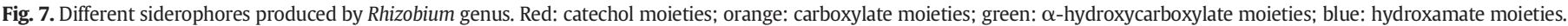
2,3-DHBA-Thr: 2,3-dihydroxybenzoic threonine. (For interpretation of the references to colour in this figure legend, the reader is referred to the web version of this article.)

phaseolina and Aspergillus niger (Sharma and Das, 2010) was also documented.

4.1.6.4. Applied studies. The development of crops such as bean (de Souza et al., 2016), green gram (Kumar et al., 2015), rice (Bhattacharjee et al., 2012), groundnut (Arora et al., 2001), crambe (de Aquino et al., 2018), lettuce or carrot (Flores-Félix et al., 2013) have been tested with the inoculation of different Rhizobium spp. The inoculation has resulted in different positive outcomes, such as increase of shoot mass (Bhattacharjee et al., 2012; de Souza et al., 2016; Flores-Félix et al., 2013), nitrogen plant content (Baba et al., 2015; Bhattacharjee et al., 2012; Flores-Félix et al., 2013) and root development (de Aquino et al., 2018) or reduced effects of pathogenic agents (Arora et al., 2001; Siddiqui et al., 2007).

4.1.6.5. Microbiological safety. Rhizobium genus has about sixty-three species identified in the TRBA-466 list, belonging all of them to risk group 1 bacteria (Committee on Biological Agents, 2015). Some species, such as Rhizobium radiobacter, have strains with plant phytopathogenicity. Rhizobium inoculation studies have shown that this genus does not have a negative impact on the native community; instead, it contributes to an increase of the bacterial community (Ambrosini et al., 2016). Therefore, considering the proven capabilities to promote plant growth without causing any harm to human health and rhizosphere communities, the bacteria belonging to Rhizobium genus can be seen as an alternative for agronomic application.

\section{Concluding remarks}

As the world's population continues to increase, as well as the quality of life in some developing countries, the demand for food of quality equally increases. The limited space available for farming means that the usable space must be worked with the best efficiency possible. On the other hand, agriculture presents some problems, such as the development of chlorotic plants due to the iron limitation, which is particularly severe under calcareous soils, or the loss of crops due diseases caused by phytopathogenic microorganisms. Both cases contribute to the reduction of crops yield. In addition, the intensive agriculture practice carried out in the last decades, with the use of chemical fertilizers and herbicides, caused an increase of soil and water pollution. The climate changes and the intensification of areas of infertile and unproductive soil create new challenges, which require to transform the traditional farming practices into a more precise agriculture. This can be obtained with the aid of a multi-disciplinary approach using new scientific advances obtained in areas, such as biotechnology and nanotechnology.

In the present review, it was presented one of the possible solutions for the development of more sustainable agro-ecosystems: the use of bacteria to improve the quality and quantity of harvest crops. More specifically, it was discussed the suitability of some bacteria genera (Azospirillum, Azotobacter, Bacillus, Pantoea, Pseudomonas and Rhizobium) as source of biological iron-fertilizers (siderophores) and other compounds that promotes the plant growth and prevent the action of infectious agents that cause plant diseases. Additionally, the application of bacteria in different crops improvement was presented and the biosafety aspects associated with the use of microorganisms in agronomic conditions were also addressed. In Table 3, it was summarized the main characteristics of promising bacterial genera for agriculture practices. Within these bacterial genera, particular strains may be more specialized in a given trait, while others, presented a wide properties spectra. But all genera have in common the presence of strains belonging to group 1 of biological agents, which makes them safe to be used for agricultural practices.

Although, in recent years, there has been an increased interest in the exploitation of the benefits associated with the use PGPB in terms of biofertilization and biocontrol (as can be seen from the rise of the number of publications in this field, Fig. 1), more studies need to be directed toward the use of safety PGPB as inoculants or as producers of compounds (such as siderophores) with the goal to improve crop productivity and reduce environmental impacts. Thus, the development of new inoculants (using safety bacteria), the increase of inoculum efficiency and the use of PGPB treated with nanoparticles may provide a new way to reduce the aggressive impact of agrochemicals (fertilizers and pesticides), decrease the production costs and boost the yield of crops. The design of new siderophore-based formulations for correcting iron- 
induced chlorosis, eco-friendly (biodegradable), able to complex iron in environments with low bioavailability (such as calcareous soils) and with the ability to deliver efficiently iron to plants remains an important research area.

\section{Acknowledgments}

Carlos Ferreira would like to thank the support from his grant with reference SFRH/BD/95490/2013 from FCT.

\section{Funding source}

This work was financed by the FEDER funds through the Operational Competitiveness Factors Program - COMPETE and by National Funds through FCT - Foundation for Science and Technology within the scope of the project PTDC-AGR-TEC/0458/2014 - POCI-01-0145-FEDER016681.

\section{Declaration of interest}

The authors declare that they have no conflict of interest.

\section{References}

Ahmad, F., Ahmad, I., Khan, M.S., 2008. Screening of free-living rhizospheric bacteria for their multiple plant growth promoting activities. Microbiol. Res. 163, 173-181. https://doi.org/10.1016/j.micres.2006.04.001.

Ahmed, E., Holmström, S.J.M., 2014a. Siderophores in environmental research: roles and applications. Microb. Biotechnol. 7, 196-208. https://doi.org/10.1111/17517915.12117.

Ahmed, E., Holmström, S.J.M., 2014b. The effect of soil horizon and mineral type on the distribution of siderophores in soil. Geochim. Cosmochim. Acta 131, 184-195. https://doi.org/10.1016/j.gca.2014.01.031.

Ait Bahadou, S., Ouijja, A., Karfach, A., Tahiri, A., Lahlali, R., 2018. New potential bacterial antagonists for the biocontrol of fire blight disease (Erwinia amylovora) in Morocco. Microb. Pathog. 117, 7-15. https://doi.org/10.1016/j.micpath.2018.02.011.

Akram, W., Anjum, T., Ali, B., 2015. Co-cultivation of tomato with two Bacillus strains: effects on growth and yield. J. Anim. Plant Sci. 25, 1644-1651.

Alcañiz, S., Jordá, J.D., Cerdán, M., 2017. Effectiveness of iron ethylenediamine- $N, N$ '-bis (hydroxyphenylacetic) acid (o,o-EDDHA $\left./ \mathrm{Fe}^{3}\right)$ formulations with different ratios of meso and $d, l$-racemic isomers as iron fertilizers. J. Agric. Food Chem. 65, 253-259. https://doi.org/10.1021/acs.jafc.6b03274.

Alexander, P., Brown, C., Arneth, A., Dias, C., Finnigan, J., Moran, D., Rounsevell, M.D.A., 2017. Could consumption of insects, cultured meat or imitation meat reduce global agricultural land use? Glob. Food Sec. 15, 22-32. https://doi.org/10.1016/j. gfs.2017.04.001.

Alvarez-Fernández, A., Cremonini, M.A., Sierra, M.A., Placucci, G., Lucena, J.J., 2002. Nature of impurities in fertilizers containing EDDHMA $/ \mathrm{Fe}^{3}, \mathrm{EDDHSA} / \mathrm{Fe}^{3}$, and EDDCHA $/ \mathrm{Fe}^{3}$ chelates. J. Agric. Food Chem. 50, 284-290. https://doi.org/10.1021/jf010858n.

Ambrosini, A., de Souza, R., Passaglia, L.M.P., 2016. Ecological role of bacterial inoculants and their potential impact on soil microbial diversity. Plant Soil 400, 193-207. https://doi.org/10.1007/s11104-015-2727-7.

de Aquino, G.S. Ventura, M.U., Alexandrino, R.P. Michelon, T.A. de Araujo Pescador, P.G. Nicio, T.T., Watanabe, V.S., Diniz, T.G., de Oliveira, A.L.M., Hata, F.T., 2018. Plantpromoting rhizobacteria Methylobacterium komagatae increases crambe yields, root system and plant height. Ind. Crop. Prod. 121, 277-281. https://doi.org/10.1016/j. indcrop.2018.05.020.

Arfaoui, A., Sifi, B., Boudabous, A., El Hadrami, I., Chérif, M., 2006. Identification of Rhizobium isolates possessing antagonistic activity against Fusarium oxysporum f.sp. ciceris, the causal agent of Fusarium wilt of chickpea. J. Plant Pathol. 88, 67-75.

Arora, N.K., Kang, S.C., Maheshwari, D.K., 2001. Isolation of siderophore-producing strains of Rhizobium meliloti and their biocontrol potential against Macrophomina phaseolina that causes charcoal rot of groundnut. Curr. Sci. 81, 673-677.

Baars, O., Zhang, X., Morel, F.M.M., Seyedsayamdost, M.R., 2016. The siderophore metabolome of Azotobacter vinelandii. Appl. Environ. Microbiol. 82, 27-39. https://doi.org/ 10.1128/AEM.03160-15.

Baba, Z.A., Aziz, M.A., Sheikh, T.A., Sheikh, F.A., Bhat, Z.A., Khan, S., Saher, T., Hamid, B., 2015. Studies on soil health and plant growth promoting potential of Rhizobium isolates. Emirates J. Food Agric. 27, 423-429. https://doi.org/10.9755/ ejfa.2015.04.043.

Bachhawat, A.K., Ghosh, S., 1987. Iron transport in Azospirillum brasilense: role of the siderophore spirilobactin. Microbiology 133, 1759-1765. https://doi.org/10.1099/ 00221287-133-7-1759.

Backer, R., Rokem, J.S., Ilangumaran, G., Lamont, J., Praslickova, D., Ricci, E., Subramanian, S., Smith, D.L., 2018. Plant growth-promoting rhizobacteria: context, mechanisms of action, and roadmap to commercialization of biostimulants for sustainable agriculture. Front. Plant Sci. 9. https://doi.org/10.3389/fpls.2018.01473.

Bailey, D.C., Alexander, E., Rice, M.R., Drake, E.J., Mydy, L.S., Aldrich, C.C., Gulick, A.M., 2018. Structural and functional delineation of aerobactin biosynthesis in hypervirulent
Klebsiella pneumoniae. J. Biol. Chem. 293, 7841-7852. https://doi.org/10.1074/jbc. RA118.002798.

Banik, A., Mukhopadhaya, S.K., Dangar, T.K., 2016. Characterization of $\mathrm{N}_{2}$-fixing plant growth promoting endophytic and epiphytic bacterial community of Indian cultivated and wild rice (Oryza spp.) genotypes. Planta 243, 799-812. https://doi.org/ 10.1007/s00425-015-2444-8.

Barbeau, K., Rue, E.L., Trick, C.G., Bruland, K.W., Butler, A., 2003. Photochemical reactivity of siderophores produced by marine heterotrophic bacteria and cyanobacteria, based on characteristic Fe(III) binding groups. Limnol. Oceanogr. 48, 1069-1078. https:// doi.org/10.4319/lo.2003.48.3.1069.

Barker, A.V., Stratton, M.L., 2015. Iron. In: Barker, A.V., Pilbeam, D.J. (Eds.), Handbook of Plant Nutrition. CRC Press, Boca Raton, Florida, EUA, pp. 399-426.

Barry, S.M., Challis, G.L., 2009. Recent advances in siderophore biosynthesis. Curr. Opin. Chem. Biol. 13, 205-215. https://doi.org/10.1016/j.cbpa.2009.03.008.

Barton, L.L., Abadia, J., 2006. Iron Nutrition in Plants and Rhizospheric Microorganisms. Springer Netherlands, Dordrecht https://doi.org/10.1007/1-4020-4743-6.

Bashan, Y., Harrison, S.K., Whitmoyer, R.E., 1990. Enhanced growth of wheat and soybean plants inoculated with Azospirillum brasilense is not necessarily due to general enhancement of mineral uptake. Appl. Environ. Microbiol. 56, 769-775.

Bashmakova, E.B., Pashkovskiy, P.P., Radyukina, N.L., Kuznetsov, V.V., 2015. Possible mechanism of iron deficit development in Mimulus guttatus plants exposed to joint action of nickel and zinc salts. Russ. J. Plant Physiol. 62, 761-771. https://doi.org/ $10.1134 /$ S1021443715060023.

Basu, S., Rabara, R., Negi, S., 2017. Towards a better greener future - an alternative strategy using biofertilizers. I: plant growth promoting bacteria. Plant Gene 12, 43-49. https:// doi.org/10.1016/j.plgene.2017.07.004.

Baune, M., Qi, Y., Scholz, K., Volmer, D.A., Hayen, H., 2017. Structural characterization of pyoverdines produced by Pseudomonas putida KT2440 and Pseudomonas taiwanensis VLB120. BioMetals https://doi.org/10.1007/s10534-017-0029-7.

Beiderbeck, H., Risse, D., Budzikiewicz, H., Taraz, K., 1999. A new pyoverdin from Pseudomonas aureofaciens. Zeitschrift fur Naturforsch. - Sect. C J. Biosci. 54, 1-5. https://doi. org/10.1515/znc-1999-1-202.

Belimov, A.A., Safronova, V.I., Sergeyeva, T.A., Egorova, T.N., Matveyeva, V.A., Tsyganov, V.E., Borisov, A.Y., Tikhonovich, I.A., Kluge, C., Preisfeld, A., Dietz, K.-J., Stepanok, V.V., 2001. Characterization of plant growth promoting rhizobacteria isolated from polluted soils and containing 1-aminocyclopropane-1-carboxylate deaminase. Can. J. Microbiol. 47, 642-652. https://doi.org/10.1139/w01-062.

Bellone, C.H., de Bellone, S.C., Cordileone, V., 2011. Related growth parameters in soybean plants inoculated with Azospirillum brasilense. J. Crop Improv. 25, 472-487. https:// doi.org/10.1080/15427528.2011.583716.

Beneduzi, A., Ambrosini, A., Passaglia, L.M.P., 2012. Plant growth-promoting rhizobacteria (PGPR): their potential as antagonists and biocontrol agents. Genet. Mol. Biol. 35 1044-1051. https://doi.org/10.1590/S1415-47572012000600020.

Berta, G., Copetta, A., Gamalero, E., Bona, E., Cesaro, P., Scarafoni, A., D'Agostino, G., 2014 Maize development and grain quality are differentially affected by mycorrhizal fungi and a growth-promoting pseudomonad in the field. Mycorrhiza 24, 161-170. https:// doi.org/10.1007/s00572-013-0523-x.

Bhattacharjee, R.B., Jourand, P., Chaintreuil, C., Dreyfus, B., Singh, A., Mukhopadhyay, S.N. 2012. Indole acetic acid and ACC deaminase-producing Rhizobium leguminosarum bv. trifolii SN10 promote rice growth, and in the process undergo colonization and chemotaxis. Biol. Fertil. Soils 48, 173-182. https://doi.org/10.1007/s00374-011-0614-9.

Bhattacharyya, P.N., Jha, D.K., 2012. Plant growth-promoting rhizobacteria (PGPR): emergence in agriculture. World J. Microbiol. Biotechnol. 28, 1327-1350. https://doi.org/ 10.1007/s11274-011-0979-9.

Bloem, E., Haneklaus, S., Haensch, R., Schnug, E., 2017. EDTA application on agricultural soils affects microelement uptake of plants. Sci. Total Environ. 577, 166-173. https://doi.org/10.1016/j.scitotenv.2016.10.153.

Blumer, C., Haas, D., 2000. Mechanism, regulation, and ecological role of bacteria cyanide biosynthesis. Arch. Microbiol. 173, 170-177. https://doi.org/10.1007/ s002039900127.

Bona, E., Lingua, G., Manassero, P., Cantamessa, S., Marsano, F., Todeschini, V., Copetta, A D'Agostino, G., Massa, N., Avidano, L., Gamalero, E., Berta, G., 2015. AM fungi and PGP pseudomonads increase flowering, fruit production, and vitamin content in strawberry grown at low nitrogen and phosphorus levels. Mycorrhiza 25, 181-193. https://doi.org/10.1007/s00572-014-0599-y.

Bona, E., Cantamessa, S., Massa, N., Manassero, P., Marsano, F., Copetta, A., Lingua, G., D'Agostino, G., Gamalero, E., Berta, G., 2017. Arbuscular mycorrhizal fungi and plant growth-promoting pseudomonads improve yield, quality and nutritional value of tomato: a field study. Mycorrhiza 27, 1-11. https://doi.org/10.1007/s00572-016-0727-y.

Borer, P., Hug, S.J., 2014. Photo-redox reactions of dicarboxylates and $\alpha$ hydroxydicarboxylates at the surface of Fe(III)(hydr)oxides followed with in situ ATR-FTIR spectroscopy. J. Colloid Interface Sci. 416, 44-53. https://doi.org/10.1016/j. jcis.2013.10.030

Borer, P., Kraemer, S.M., Sulzberger, B., Hug, S.J., Kretzschmar, R., 2009. Photodissolution of lepidocrocite $(\gamma-\mathrm{FeOOH})$ in the presence of desferrioxamine $\mathrm{B}$ and aerobactin. Geochim. Cosmochim. Acta 73, 4673-4687. https://doi.org/10.1016/j.gca.2009.05.049.

Brady, C.L., Venter, S.N., Cleenwerck, I., Engelbeen, K., Vancanneyt, M., Swings, J., Coutinho, T.A., 2009. Pantoea vagans sp. nov., Pantoea eucalypti sp. nov., Pantoea deleyi sp. nov. and Pantoea anthophila sp. nov. Int. J. Syst. Evol. Microbiol. 59, 2339-2345. https:// doi.org/10.1099/ijs.0.009241-0.

Brady, C.L., Goszczynska, T., Venter, S.N., Cleenwerck, I., de Vos, P., Gitaitis, R.D., Coutinho, T.A., 2011. Pantoea allii sp. nov., isolated from onion plants and seed. Int. J. Syst. Evol. Microbiol. 61, 932-937. https://doi.org/10.1099/ijs.0.022921-0.

Briat, J.-F., Dubos, C., Gaymard, F., 2015. Iron nutrition, biomass production, and plant product quality. Trends Plant Sci. 20, 33-40. https://doi.org/10.1016/j. tplants.2014.07.005. 
Briskot, G., Taraz, K., Budzikiewicz, H., 1986. Pyoverdine type siderophores from Pseudomonas aeruginosa. Zeitschrift für Naturforsch. C 41, 497-506. https://doi.org/ 10.1515/znc-1986-5-601.

Broadley, M., Brown, P., Cakmak, I., Rengel, Z., Zhao, F., 2012. Function of nutrients. Marschner's Mineral Nutrition of Higher Plants. Elsevier, pp. 191-248 https://doi. org/10.1016/B978-0-12-384905-2.00007-8.

Bucheli-Witschel, M., Egli, T., 2001. Environmental fate and microbial degradation of aminopolycarboxylic acids. FEMS Microbiol. Rev. 25, 69-106. https://doi.org/ 10.1016/S0168-6445(00)00055-3.

Bulen, W.A., LeComte, J.R., 1962. Isolation and properties of a yellow-green fluorescent peptide from Azotobacter medium. Biochem. Biophys. Res. Commun. 9, 523-528. https://doi.org/10.1016/0006-291X(62)90119-5.

Bunk, B., Schulz, A., Stammen, S., Münch, R., Warren, M.J., Rohde, M., Jahn, D., Biedendieck, R., 2010. A short story about a big magic bug. Bioeng. Bugs 1, 85-91. https://doi.org/ 10.4161/bbug.1.2.11101.

Burbank, L., Mohammadi, M., Roper, M.C., 2015. Siderophore-mediated iron acquisition influences motility and is required for full virulence of the xylem-dwelling bacteria phytopathogen Pantoea stewartii subsp. stewartii. Appl. Environ. Microbiol. 81, 139-148. https://doi.org/10.1128/AEM.02503-14.

Byers, B.R., Powell, M.V., Lankford, C.E., 1967. Iron-chelating hydroxamic acid (schizokinen) active in initiation of cell division in Bacillus megaterium. J. Bacteriol. 93, 286-294.

Campestre, M.P., Castagno, L.N., Estrella, M.J., Ruiz, O.A., 2016. Lotus japonicus plants of the Gifu B-129 ecotype subjected to alkaline stress improve their $\mathrm{Fe}^{2}$ bio-availability through inoculation with Pantoea eucalypti M91. J. Plant Physiol. 192, 47-55. https://doi.org/10.1016/j.jplph.2016.01.001.

Cassán, F.D., Diaz-Zorita, M., 2016. Azospirillum sp. in current agriculture: from the laboratory to the field. Soil Biol. Biochem. 103, 117-130. https://doi.org/10.1016/j. soilbio.2016.08.020.

Cecagno, R., Fritsch, T.E., Schrank, I.S., 2015. The plant growth-promoting bacteria Azospirillum amazonense: genomic versatility and phytohormone pathway. Biomed. Res. Int. 2015, 1-7. https://doi.org/10.1155/2015/898592.

Chaney, R.L., Chen, Y., Green, C.E., Holden, M.J., Bell, P.F., Luster, D.G., Angle, J.S., 2008. Root hairs on chlorotic tomatoes are an effect of chlorosis rather than part of the adaptive Fe-stress-response. J. Plant Nutr. 15, 1857-1875. https://doi.org/10.1080/ 01904169209364444.

Chauhan, S., Wadhwa, K., Vasudeva, M., Narula, N., 2012. Potential of Azotobacter spp. as biocontrol agents against Rhizoctonia solani and Fusarium oxysporum in cotton (Gossypium hirsutum), guar (Cyamopsis tetragonoloba) and tomato (Lycopersicum esculentum). Arch Agron. Soil Sci. 58, 1365-1385. https://doi.org/10.1080/03650340.2011.590134.

Chauhan, H., Bagyaraj, D.J., Selvakumar, G., Sundaram, S.P., 2015. Novel plant growth promoting rhizobacteria-prospects and potential. Appl. Soil Ecol. 95, 38-53. https://doi. org/10.1016/j.apsoil.2015.05.011

Cocking, E.C., 2003. Endophytic colonization of plant roots by nitrogen-fixing bacteria Plant Soil 252, 169-175. https://doi.org/10.1023/A:1024106605806.

Collinson, S.K., Doran, J.L., Page, W.J., 1987. Production of 3,4-dihydroxybenzoic acid by Azomonas macrocytogenes and Azotobacter paspali. Can. J. Microbiol. 33, 169-175.

Colombo, C., Palumbo, G., He, J.-Z., Pinton, R., Cesco, S., 2014. Review on iron availability in soil: interaction of Fe minerals, plants, and microbes. J. Soils Sediments 14, 538-548. https://doi.org/10.1007/s11368-013-0814-z.

Committee on Biological Agents, 2015. Classification of Prokaryotes (Bacteria and Archaea) into Risk Groups. Bundesanstalt für Arbeitsschutz and Arbeitsmedizin, Berlin

Corbin, J.L., Bulen, W.A., 1969. Isolation and identification of 2,3-dihydroxybenzoic acid and 2-N,6-N-di(2,3-dihydroxybenzoyl)-L-lysine formed by iron-deficient Azotobacter vinelandii. Biochemistry 8, 757-762. https://doi.org/10.1021/bi00831a002.

Cornish, A.S., Page, W.J., 1995. Production of the triacetecholate siderophore protochelin by Azotobacter vinelandii. Biometals 8, 332-338. https://doi.org/10.1007/BF00141607.

Coulthurst S.J. 2014. Role of the phosphopantetheinyltransferase enzyme, PswP, in the biosynthesis of antimicrobial secondary metabolites by Serratia marcescens Db10. Microbiology 160, 1609-1617. https://doi.org/10.1099/mic.0.078576-0.

Cox, C.D., 1986. Role of pyocyanin in the acquisition of iron from transferrin. Infect. Immun. 52, 263-270.

Cox, C.D., Graham, R., 1979. Isolation of an iron-binding compound from Pseudomona aeruginosa. J. Bacteriol. 137, 357-364.

Cox, C.D., Rinehart, K.L., Moore, M.L., Cook, J.C., 1981. Pyochelin: novel structure of an iron-chelating growth promoter for Pseudomonas aeruginosa. Proc. Natl. Acad. Sci. U. S. A. 78, 4256-4260. https://doi.org/10.1073/pnas.78.7.4256.

Datta, A., Singh, R.K., Tabassum, S., 2015. Isolation, characterization and growth of Rhizobium strains under optimum conditions for effective biofertilizer production. Int J. Pharm. Sci. Rev. Res. 31, 199-208.

De La Fuente, L., Quagliotto, L., Bajsa, N., Fabiano, E., Altier, N., Arias, A., 2002. Inoculation with Pseudomonas fiuorescens biocontrol strains does not affect the symbiosis between rhizobia and forage legumes. Soil Biol. Biochem. 34, 545-548. https://doi. org/10.1016/S0038-0717(01)00194-8.

Deori, M., Jayamohan, N.S., Kumudini, B.S., 2018. Production, characterization and iron binding affinity of hydroxamate siderophores from rhizosphere associated fluorescent Pseudomonas. J. Plant Prot. Res. 58. https://doi.org/10.24425/119116.

Desbrosses, G., Contesto, C., Varoquaux, F., Galland, M., Touraine, B., 2009. PGPRArabidopsis interactions is a useful system to study signaling pathways involved in plant developmental control. Plant Signal. Behav. 4, 319-321. https://doi.org/ 10.4161/psb.4.4.8106.

Diaz-Barrera, A., Soto, E., 2010. Biotechnological uses of Azotobacter vinelandii: current state, limits and prospects. African J. Biotechnol. 9, 5240-5250. https://doi.org/ 10.5897/AJB10.025.

Drinkwater, L.E., Schipanski, M., Snapp, S., Jackson, L.E., 2017. Ecologically based nutrient management. Agricultural Systems: Agroecology and Rural Innovation for Development. Elsevier, pp. 203-257 https://doi.org/10.1016/B978-0-12-802070-8.00007-4.
Dubey, R.C., Maheshwari, D.K., Kumar, V., Pandey, R.R., 2012. Growth enhancement of Sesamum indicum L. by rhizosphere-competent Azotobacter chroococcum AZO2 and its antagonistic activity against Macrophomina phaseolina. Arch. Phytopathol. Plant Prot. 45, 437-454. https://doi.org/10.1080/03235408.2011.587979.

Dubois, M. Van den Broeck, L. Inzé, D., 2018. The pivotal role of ethylene in plant growth. Trends Plant Sci. 23, 311-323. https://doi.org/10.1016/j.tplants.2018.01.003.

Duca, D., Lorv, J., Patten, C.L., Rose, D., Glick, B.R., 2014. Indole-3-acetic acid in plantmicrobe interactions. Antonie Van Leeuwenhoek 106, 85-125. https://doi.org/ 10.1007/s10482-013-0095-y.

Duhme, A.K., Hider, R.C., Naldrett, M.J., Pau, R.N., 1998. The stability of the molybdenumazotochelin complex and its effect on siderophore production in Azotobacter vinelandii. J. Biol. Inorg. Chem. 3, 520-526. https://doi.org/10.1007/s007750050263.

Dunlap, C.A., Bowman, M.J., Schisler, D.A., 2013. Genomic analysis and secondary metabolite production in Bacillus amyloliquefaciens AS 43.3: a biocontrol antagonist of Fusarium head blight. Biol. Control 64, 166-175. https://doi.org/10.1016/j. biocontrol.2012.11.002.

Dutta, S., Podile, A.R., 2010. Plant growth promoting rhizobacteria (PGPR): the bugs to debug the root zone. Crit. Rev. Microbiol. 36, 232-244. https://doi.org/10.3109/ 10408411003766806

Eng-Wilmot, D.L., Van der Helm, D., 1980. Molecular and crystal structure of the linear tricatechol siderophore, agrobactin. J. Am. Chem. Soc. 102, 7719-7725. https://doi. org/10.1021/ja00546a014.

European Union, 2000. Directive 2000/54/EC of the European Parliament and of the Council of 18 September 2000 on the protection of workers from risks related to exposure to biological agents at work (seventh individual directive within the meaning of Article 16(1) of Directive). Off. J. Eur. Union L 262, 21-45.

European Union, 2003. Regulation (EC) No 2003/2003 of the European Parliament and of the Council of 13 October 2003 relating to fertilizers. Off. J. Eur. Union L 304, 1-194.

Farajzadeh, D., Yakhchali, B., Aliasgharzad, N., Sokhandan-Bashir, N., Farajzadeh, M., 2012. Plant growth promoting characterization of indigenous azotobacteria isolated from soils in Iran. Curr. Microbiol. 64, 397-403. https://doi.org/10.1007/s00284-012-0083-x.

Fasciglione, G., Casanovas, E.M., Quillehauquy, V., Yommi, A.K., Goñi, M.G., Roura, S.I., Barassi, C.A. 2015. Azospirillum inoculation effects on growth, product quality and storage life of lettuce plants grown under salt stress. Sci. Hortic. (Amsterdam). 195, 154-162. https://doi.org/10.1016/j.scienta.2015.09.015.

Fatima, Z. Saleemi, M.,Zia, M.,Sultan, T., Aslam, M., Rehman, R.-U., Chaudhary, M.F., 2009. Antifungal activity of plant growth-promoting rhizobacteria isolates against Rhizoctonia solani in wheat. African J. Biotechnol. 8, 219-225.

Fazary, A.E., Ju, Y.H., Al-Shihri, A.S., Alfaifi, M.Y., Alshehri, M.A., 2016. Biodegradable siderophores: survey on their production, chelating and complexing properties. Rev. Inorg. Chem. 36, 153-181. https://doi.org/10.1515/revic-2016-0002.

Feistner, G.J., Ishimaru, C., 1996. Proferrioxamine profiles of Erwinia herbicola and related bacteria. Biometals 9, 337-344.

Fekete, F.A., Spence, J.T., Emery, T., 1983. Siderophores produced by nitrogen-fixing Azotobacter vinelandii $\mathrm{OP}$ in iron-limited continuous culture. Appl. Environ. Microbiol. 46, 1297-1300.

Felici, C., Vettori, L., Giraldi, E., Forino, L.M.C., Toffanin, A., Tagliasacchi, A.M., Nuti, M., 2008. Single and co-inoculation of Bacillus subtilis and Azospirillum brasilense on Lycopersicon esculentum: effects on plant growth and rhizosphere microbial community. Appl. Soil Ecol. 40, 260-270. https://doi.org/10.1016/j.apsoil.2008.05.002.

Feng, Y., Shen, D., Song, W., 2006. Rice endophyte Pantoea agglomerans YS19 promotes host plant growth and affects allocations of host photosynthates. J. Appl. Microbiol. 100, 938-945. https://doi.org/10.1111/j.1365-2672.2006.02843.x.

Ferreira, C.M.H., Sousa, C.A., Sanchis-Pérez, I., López-Rayo, S., Barros, M.T., Soares, H.M.V.M., Lucena, J.J., 2019. Calcareous soil interactions of the iron(III) chelates of $\mathrm{DPH}$ and Azotochelin and its application on amending iron chlorosis in soybean (Glycine max). Sci. Total Environ. 647, 1586-1593. https://doi.org/10.1016/j. scitotenv.2018.08.069.

Flores-Félix, J.D., Menéndez, E., Rivera, L.P., Marcos-García, M., Martínez-Hidalgo, P., Mateos, P.F., Martínez-Molina, E., Velázquez, M. de la E., García-Fraile, P., Rivas, R. 2013. Use of Rhizobium leguminosarum as a potential biofertilizer for Lactuca sativa and Daucus carota crops. J. Plant Nutr. Soil Sci. 176, 876-882. https://doi.org/ 10.1002/jpln.201300116.

Fones, H., Gurr, S., 2015. The impact of Septoria tritici Blotch disease on wheat: an EU perspective. Fungal Genet. Biol. 79, 3-7. https://doi.org/10.1016/j.fgb.2015.04.004.

Franco-Correa, M., Quintana, A., Duque, C., Suarez, C., Rodríguez, M.X., Barea, J.-M., 2010. Evaluation of actinomycete strains for key traits related with plant growth promotion and mycorrhiza helping activities. Appl. Soil Ecol. 45, 209-217. https://doi.org/ 10.1016/j.apsoil.2010.04.007.

Friedrich, C.G., Rother, D., Bardischewsky, F., Quentmeier, A., Fischer, J., 2001. Oxidation of reduced inorganic sulfur compounds by bacteria: emergence of a common mechanism? Appl. Environ. Microbiol. 67, 2873-2882. https://doi.org/10.1128/AEM.67.7.28732882.2001.

Fukami, J., Nogueira, M.A., Araujo, R.S., Hungria, M., 2016. Accessing inoculation methods of maize and wheat with Azospirillum brasilense. AMB Express 6, 1-13. https://doi. org/10.1186/s13568-015-0171-y.

Fukasawa, K., Goto, M., Sasaki, K., Hirata, Y., Sato, S., 1972. Structure of the yellow-green fluorescent peptide produced by iron-deficient Azotobacter vinelandii strain $\mathrm{O}$. Tetrahedron 28, 5359-5365. https://doi.org/10.1016/S0040-4020(01)93858-X.

Gadagi, R.S., Krishnaraj, P., Kulkarni, J., Sa, T., 2004. The effect of combined Azospirillum inoculation and nitrogen fertilizer on plant growth promotion and yield response of the blanket flower Gaillardia pulchella. Sci. Hortic. (Amsterdam). 100, 323-332. https:// doi.org/10.1016/j.scienta.2003.10.002.

Gáll, T., Lehoczki, G., Gyémánt, G., Emri, T., Szigeti, Z.M., Balla, G., Balla, J., Pócsi, I., 2016. Optimization of desferrioxamine E production by Streptomyces parvulus. Acta Microbiol. Immunol. Hung. 63, 475-489. https://doi.org/10.1556/030.63.2016.029. 
Gamalero, E., Berta, G., Massa, N., Glick, B.R., Lingua, G., 2008. Synergistic interactions between the ACC deaminase-producing bacterium Pseudomonas putida UW4 and the AM fungus Gigaspora rosea positively affect cucumber plant growth. FEMS Microbiol. Ecol. 64, 459-467. https://doi.org/10.1111/j.1574-6941.2008.00485.x.

García de Salamone, I.E., Funes, J.M., Di Salvo, L.P., Escobar-Ortega, J.S., D'Auria, F. Ferrando, L., Fernandez-Scavino, A., 2012. Inoculation of paddy rice with Azospirillum brasilense and Pseudomonas fluorescens: impact of plant genotypes on rhizosphere microbial communities and field crop production. Appl. Soil Ecol. 61, 196-204. https://doi.org/10.1016/j.apsoil.2011.12.012.

García, J.E., Maroniche, G., Creus, C., Suárez-Rodríguez, R., Ramirez-Trujillo, J.A., Groppa, M.D., 2017. In vitro PGPR properties and osmotic tolerance of different Azospirillum native strains and their effects on growth of maize under drought stress. Microbiol. Res. 202, 21-29. https://doi.org/10.1016/j.micres.2017.04.007.

García-Marco, S., Martínez, N., Yunta, F., Hernández-Apaolaza, L., Lucena, J.J., 2006. Effectiveness of ethylenediamine- $\mathrm{N}$ (o-hydroxyphenylacetic) $-\mathrm{N}^{\prime}(p$ - hydroxyphenylacetic) acid (o,p-EDDHA) to supply iron to plants. Plant Soil 279, 31-40. https://doi.org/ 10.1007/s11104-005-8218-5.

Glick, B.R., 2010. Using soil bacteria to facilitate phytoremediation. Biotechnol. Adv. 28, 367-374. https://doi.org/10.1016/j.biotechadv.2010.02.001.

Glick, B.R., 2012. Plant growth-promoting bacteria: mechanisms and applications. Scientifica (Cairo) 2012, 1-15. https://doi.org/10.6064/2012/963401.

Glick, B.R., 2014. Bacteria with ACC deaminase can promote plant growth and help to feed the world. Microbiol. Res. 169, 30-39. https://doi.org/10.1016/j.micres.2013.09.009.

Gonzalez, A.J., Larraburu, E.E., Llorente, B.E., 2015. Azospirillum brasilense increased salt tolerance of jojoba during in vitro rooting. Ind. Crop. Prod. 76, 41-48. https://doi. org/10.1016/j.indcrop.2015.06.017.

Gopalakrishnan, S., Vadlamudi, S., Bandikinda, P., Sathya, A., Vijayabharathi, R., Rupela, O., Kudapa, H., Katta, K., Varshney, R.K., 2014. Evaluation of Streptomyces strains isolated from herbal vermicompost for their plant growth-promotion traits in rice. Microbiol. Res. 169, 40-48. https://doi.org/10.1016/j.micres.2013.09.008.

Gopalakrishnan, S., Srinivas, V., Samineni, S., 2017. Nitrogen fixation, plant growth and yield enhancements by diazotrophic growth-promoting bacteria in two cultivars of chickpea (Cicer arietinum L.). Biocatal. Agric. Biotechnol. 11, 116-123. https://doi. org/10.1016/j.bcab.2017.06.012.

Goudjal, Y., Zamoum, M., Meklat, A., Sabaou, N., Mathieu, F., Zitouni, A., 2016. Plantgrowth-promoting potential of endosymbiotic actinobacteria isolated from sand truffles (Terfezia leonis Tul.) of the Algerian Sahara. Ann. Microbiol. 66, 91-100. https:// doi.org/10.1007/s13213-015-1085-2.

Graumann, P.L., 2012. Bacillus: Cellular and Molecular Biology. Second ed. Caister Academic Press, Freiburg, Germany.

Guerinot, M.L., Yi, Y., 1994. Iron: nutritious, noxious, and not readily available. Plant Physiol. 104, 815-820. https://doi.org/10.1104/pp.104.3.815.

Gupta, S., Kaushal, R., Sood, G., 2018. Impact of plant growth-promoting Rhizobacteria on vegetable crop production. Int. J. Veg. Sci. 24, 289-300. https://doi.org/10.1080/ 19315260.2017.1407984.

Haas, D., Défago, G., 2005. Biological control of soil-borne pathogens by fluorescent pseudomonads. Nat. Rev. Microbiol. 3, 307-319. https://doi.org/10.1038/nrmicro1129.

Hansen, N.C., Hopkins, B.G., Ellsworth, J.W., Jolley, V.D., 2006. Iron nutrition in field crops. Iron Nutr. Plants Rhizospheric Microorg., 23-59 https://doi.org/10.1007/1-40204743-6-2.

Harrington, J.M., Duckworth, O.W., Haselwandter, K., 2015. The fate of siderophores: antagonistic environmental interactions in exudate-mediated micronutrient uptake. BioMetals 28, 461-472. https://doi.org/10.1007/s10534-015-9821-4.

Hayat, R., Ali, S., Amara, U., Khalid, R., Ahmed, I., 2010. Soil beneficial bacteria and their role in plant growth promotion: a review. Ann. Microbiol. 60, 579-598. https://doi. org/10.1007/s13213-010-0117-1.

Heidarzadeh, N., Baghaee-Ravari, S., 2015. Application of Bacillus pumilus as a potential biocontrol agent of Fusarium wilt of tomato. Arch. Phytopathol. Plant Prot. 48, 841-849. https://doi.org/10.1080/03235408.2016.1140611.

Hernández, A.G., de Moura, G.D., Binati, R.L., Nascimento, F.X.I., Londoño, D.M., Mamede, A.C.P., da Silva, E.P., de Armas, R.D., Giachini, A.J., Rossi, M.J., Soares, C.R.F.S., 2017. Selection and characterization of coal mine autochthonous rhizobia for the inoculation of herbaceous legumes. Arch. Microbiol. 199, 991-1001. https://doi.org/10.1007/ s00203-017-1373-2.

Hernández-Apaolaza, L., García-Marco, S., Nadal, P., Lucena, J.J., Sierra, M.A., GómezGallego, M., Ramírez-López, P., Escudero, R., 2006. Structure and fertilizer properties of byproducts formed in the synthesis of EDDHA. J. Agric. Food Chem. 54, 4355-4363. https://doi.org/10.1021/jf0605749.

Hider, R.C., Kong, X., 2010. Chemistry and biology of siderophores. Nat. Prod. Rep. 27, 637-657. https://doi.org/10.1039/b906679a.

Hohlneicher, U., Hartmann, R., Taraz, K., Budzikiewicz, H., 1995. Pyoverdin, Ferribactin, Azotobactin - a new Triade of Siderophores from Pseudomonas chlororaphis ATCC 9446 and its relation to Pseudomonas fluorescens ATCC 13525. Zeitschrift fur Naturforsch. - Sect. C J. Biosci. 50, 337-344. https://doi.org/10.1515/znc-1995-5-602.

Hördt, W., Römheld, V., Winkelmann, G., 2000. Fusarinines and dimerum acid, mono- and dihydroxamate siderophores from Penicillium chrysogenum, improve iron utilization by strategy I and strategy II plants. BioMetals 13, 37-46. https://doi.org/10.1023/A: 1009234612486.

Hoshino, Y., Chiba, K., Ishino, K., Fukai, T., Igarashi, Y., Yazawa, K., Mikami, Y., Ishikawa, J., 2011. Identification of nocobactin NA biosynthetic gene clusters in Nocardia farcinica. J. Bacteriol. 193, 441-448. https://doi.org/10.1128/JB.00897-10.

$\mathrm{Hu}$, X., Boyer, G.L., 1995. Isolation and characterization of the siderophore Ndeoxyschizokinen from Bacillus megaterium ATCC 19213. BioMetals 8, 357-364.

Huang, C.-N., Lin, C.-P., Hsieh, F.-C., Lee, S.-K., Cheng, K.-C., Liu, C.-T., 2016. Characterization and evaluation of Bacillus amyloliquefaciens strain WF02 regarding its biocontrol activities and genetic responses against bacterial wilt in two different resistant tomato cultivars. World J. Microbiol. Biotechnol. 32, 183. https://doi.org/10.1007/s11274016-2143-z.

Ito, T., Neilands, J.B., 1958. Products of "low-iron fermentation" with Bacillus subilis: isolation, characterization and aynthesis of 2,3-dihydroxybenzoylglycine 1,2. J. Am. Chem. Soc. 80, 4645-4647. https://doi.org/10.1021/ja01550a058.

Jiang, Z., Chen, M., Yu, X., Xie, Z., 2016. 7-Hydroxytropolone produced and utilized as an iron-scavenger by Pseudomonas donghuensis. BioMetals, 1-10 https://doi.org/ 10.1007/s10534-016-9954-0.

Jiang, Z., Li, J., Qu, L.J., 2017. Auxins. In: Li, J., Li, C., Smith, S.M. (Eds.), Hormone Metabolism and Signaling in Plants. Elsevier, pp. 39-76 https://doi.org/10.1016/B978-0-12811562-6.00002-5.

Jorquera, M.A., Crowley, D.E., Gajardo, G., Mora, M.L., 2010. Mechanisms and practical considerations involved in plant growth promotion by rhizobacteria. J. Soil Sci. Plant Nutr. 10, 293-319. https://doi.org/10.4067/S0718-95162010000100006.

Kabir, A.H., Paltridge, N., Stangoulis, J., 2016. Chlorosis correction and agronomic biofortification in field peas through foliar application of iron fertilizers under Fe deficiency. J. Plant Interact. 11, 1-4. https://doi.org/10.1080/17429145.2015.1125534.

Kamran, M.A., Eqani, S.A.M.A.S., Bibi, S., Xu, R.K., Amna, Monis, M.F.H., Katsoyiannis, A. Bokhari, H., Chaudhary, H.J., 2016. Bioaccumulation of nickel by E. sativa and role of plant growth promoting rhizobacteria (PGPRs) under nickel stress. Ecotoxicol. Environ. Saf. 126, 256-263. https://doi.org/10.1016/j.ecoenv.2016.01.002.

Kannapiran, E., Ramkumar, V.S., 2011. Inoculation effect of nitrogen-fixing and phosphate-solubilizing bacteria to promote growth of black gram (Phaseolus mungo Roxb; Eng). Ann. Biol. Res. 2, 615-621.

Kaonga, C.C., Chidya, R.C.G., Kosamu, I.B.M., Abdel-dayem, S.M., Mapoma, H.W.T., Thole, B. Mbewe, R., Sakugawa, H., 2017. Trends in usage of selected fungicides in Japan between 1962 and 2014: a review. Int. J. Environ. Sci. Technol. https://doi.org/ 10.1007/s13762-017-1565-y.

Kesaulya, H., Hasinu, J.V., Tuhumury, G.N.C., 2018. Potential of Bacillus spp produces siderophores insuppressing the wilt disease of banana plants. IOP Conf. Ser. Earth Environ. Sci. 102, 012016. https://doi.org/10.1088/1755-1315/102/1/012016.

Khamna, S., Yokota, A., Lumyong, S., 2009. Actinomycetes isolated from medicinal plant rhizosphere soils: diversity and screening of antifungal compounds, indole-3-acetic acid and siderophore production. World J. Microbiol. Biotechnol. 25, 649-655. https://doi.org/10.1007/s11274-008-9933-X.

Kim, S.N., Cho, W.K., Kim, W. Il, Jee, H.J., Park, C.S., 2012. Growth promotion of pepper plants by Pantoea ananatis B1-9 and its efficient endophytic colonization capacity in plant tissues. Plant Pathol. J. 28, 270-281. https://doi.org/10.5423/PPJ OA.02.2012.0026.

Kloepper, J.W., Schroth, M.N., 1978. Plant growth-promoting rhizobacteria on radishes. 4th Internat. Conf. Plant Pathog. Bacter. 2, pp. 879-882.

Kloepper, J.W., Leong, J., Teintze, M., Schroth, M.N., 1980. Pseudomonas siderophores: a mechanism explaining disease-suppressive soils. Curr. Microbiol. 4, 317-320. https://doi.org/10.1007/BF02602840.

Koenning, S.R., Wrather, J.A., 2010. Suppression of soybean yield potential in the continental United States by plant diseases from 2006 to 2009. Plant Heal. Prog. https:/ doi.org/10.109/PHP-2010-1122-01-RS (doi:10.1094/PHP-2010-1122-01-RS. Abstract).

Koppisch, A.T., Browder, C.C., Moe, A.L., Shelley, J.T., Kinkel, B.A., Hersman, L.E., Iyer, S., Ruggiero, C.E., 2005. Petrobactin is the primary siderophore synthesized by Bacillus anthracis str. Sterne under conditions of iron starvation. BioMetals 18, 577-585. https://doi.org/10.1007/s10534-005-1782-6.

Koppisch, A.T., Dhungana, S., Hill, K.K., Boukhalfa, H., Heine, H.S., Colip, L.A., Romero, R.B. Shou, Y., Ticknor, L.O., Marrone, B.L., Hersman, L.E., Iyer, S., Ruggiero, C.E., 2008. Petrobactin is produced by both pathogenic and non-pathogenic isolates of the Bacillus cereus group of bacteria. BioMetals 21, 581-589. https://doi.org/10.1007/s10534008-9144-9.

Kraemer, S.M., 2004. Iron oxide dissolution and solubility in the presence of siderophores Aquat. Sci. - Res. Across Boundaries 66, 3-18. https://doi.org/10.1007/s00027-0030690-5.

Kraepiel, A.M.L., Bellenger, J.P., Wichard, T., Morel, F.M.M., 2009. Multiple roles of siderophores in free-living nitrogen-fixing bacteria. BioMetals 22, 573-581. https:// doi.org/10.1007/s10534-009-9222-7.

Kumar, A., Kumar, A., Pratush, A., 2014. Molecular diversity and functional variability of environmental isolates of Bacillus species. Springerplus 3, 312. https://doi.org/ 10.1186/2193-1801-3-312.

Kumar, G.P., Desai, S., Amalraj, E.L.D., Pinisetty, S., 2015. Impact of seed bacterization with PGPR on growth and nutrient uptake in different cultivable varieties of green gram. Asian J. Agric. Res. 9, 113-122. https://doi.org/10.3923/ajar.2015.113.122.

Lenin, G., Jayanthi, M., 2012. Indole acetic acid, gibberellic acid and siderophore production by PGPR isolates from rhizospheric soils of Catharanthus roseus. Int. J. Pharm. Biol. Arch. 3, 933-938.

Leong, S.A., Neilands, J.B., 1982. Siderophore production by phytopathogenic microbia species. Arch. Biochem. Biophys. 218, 351-359. https://doi.org/10.1016/0003-9861 (82)90356-3.

Lin, S.-Y., Hameed, A., Liu, Y.-C., Hsu, Y.-H., Lai, W.-A., Shen, F.-T., Young, C.-C., 2015. Azospirillum soli sp. nov., a nitrogen-fixing species isolated from agricultural soil. Int. J. Syst. Evol. Microbiol. 65, 4601-4607. https://doi.org/10.1099/ijsem.0.000618.

Lindsay, W.L., Schwab, A.P., 1982. The chemistry of iron in soils and its availability to plants. J. Plant Nutr. 5, 821-840. https://doi.org/10.1080/01904168209363012.

Liu, P.V., Shokrani, F., 1978. Biological activities of pyochelins: iron-chelating agents of Pseudomonas aeruginosa. Infect. Immun. 22, 878-890.

Liu, D., Yang, Q., Ge, K., Hu, X., Qi, G., Du, B., Liu, K., Ding, Y., 2017. Promotion of iron nutrition and growth on peanut by Paenibacillus illinoisensis and Bacillus sp. strains in calcareous soil. Brazilian J. Microbiol. 48, 656-670. https://doi.org/10.1016/j. bjm.2017.02.006. 
Loaces, I., Ferrando, L., Scavino, A.F., 2011. Dynamics, diversity and function of endophytic siderophore-producing bacteria in rice. Microb. Ecol. 61, 606-618. https://doi.org/ 10.1007/s00248-010-9780-9.

Lodwig, E.M., Hosie, A.H.F., Bourdès, A., Findlay, K., Allaway, D., Karunakaran, R., Downie, J.A., Poole, P.S., 2003. Amino-acid cycling drives nitrogen fixation in the legumerhizobium symbiosis. Nature 422, 722-726. https://doi.org/10.1038/nature01527.

López-Rayo, S., Hernández, D., Lucena, J.J., 2009. Chemical evaluation of HBED/Fe $\mathrm{F}^{3}$ and the novel $\mathrm{HJB} / \mathrm{Fe}^{3-}$ chelates as fertilizers to alleviate iron chlorosis. J. Agric. Food Chem. 57, 8504-8513. https://doi.org/10.1021/jf9019147.

López-Rayo, S., Sanchis-Pérez, I., Ferreira, C.M.H., Lucena, J.J., 2019. [S,S]-EDDS/Fe: a new chelate for the environmentally sustainable correction of iron chlorosis in calcareous soil. Sci. Total Environ. 647, 1508-1517. https://doi.org/10.1016/j. scitotenv.2018.08.021.

Lucena, J.J., 2000. Effects of bicarbonate, nitrate and other environmental factors on iron deficiency chlorosis. A review. J. Plant Nutr. 23, 1591-1606. https://doi.org/10.1080/ 01904160009382126

Lucena, J.J., 2003. Fe chelates for remediation of Fe chlorosis in strategy I plants. J. Plant Nutr. 26, 1969-1984. https://doi.org/10.1081/PLN-120024257.

Madigan, M.T., Martinko, J.M., 2006. Brock - Biology of Microorganisms. 11th ed. Pearson Prentice Hall, London.

Mahato, S., Kafle, A., 2018. Comparative study of Azotobacter with or without other fertilizers on growth and yield of wheat in Western hills of Nepal. Ann. Agrar. Sci. 16, 250-256. https://doi.org/10.1016/j.aasci.2018.04.004.

Maienfisch, P., Stevenson, T.M., 2015. Modern agribusiness - markets, companies, benefits and challenges. In: Maienfisch, P., Stevenson, T.M. (Eds.), Discovery and Synthesis of Crop Protection Products. American Chemical Society, pp. 1-13 https://doi.org/ 10.1021/bk-2015-1204.ch001.

Mamta, Rahi, P., Pathania, V., Gulati, A., Singh, B., Bhanwra, R.K., Tewari, R., 2010. Stimulatory effect of phosphate-solubilizing bacteria on plant growth, stevioside and rebaudioside-A contents of Stevia rebaudiana Bertoni. Appl. Soil Ecol. 46, 222-229. https://doi.org/10.1016/j.apsoil.2010.08.008.

May, J.J., Wendrich, T.M., Marahiel, M.A., 2001. The dhb operon of Bacillus subtilis encodes the biosynthetic template for the catecholic siderophore 23-dihydroxybenzoate-glycine-threonine trimeric ester bacillibactin. J. Biol. Chem. 276, 7209-7217. https://doi. org/10.1074/jbc.M009140200.

Mayak, S., Tirosh, T., Glick, B.R., 2004. Plant growth-promoting bacteria confer resistance in tomato plants to salt stress. Plant Physiol. Biochem. 42, 565-572. https://doi.org/ 10.1016/j.plaphy.2004.05.009.

McRose, D.L., Baars, O., Morel, F.M.M., Kraepiel, A.M.L., 2017. Siderophore production in Azotobacter vinelandii in response to Fe- Mo- and V-limitation. Environ. Microbiol. 19, 3595-3605. https://doi.org/10.1111/1462-2920.13857.

Mehta, P., Chauhan, A., Mahajan, R., Mahajan, P.K., Shirkot, C.K., 2010. Strain of Bacillus circulans isolated from apple rhizosphere showing plant growth promoting potential. Curr. Sci. 98, 538-542.

Mengel, K., 1994. Iron availability in plant tissues-iron chlorosis on calcareous soils. Plant Soil 165, 275-283. https://doi.org/10.1007/BF00008070.

Meyer, J.M., Abdallah, M.A., 1978. The fluorescent pigment of Pseudomonas fluorescens: biosynthesis, purification and physicochemical properties. J. Gen. Microbiol. 107, 319-328. https://doi.org/10.1099/00221287-107-2-319.

Meyer, J.M., Stintzi, A., De Vos, D., Cornelis, P., Tappe, R., Taraz, K., Budzikiewicz, H., 1997. Use of siderophores to type pseudomonads: the three Pseudomonas aeruginosa pyoverdine systems. Microbiology 143, 35-43. https://doi.org/10.1099/00221287-143-1-35.

Meyer, J.M., Geoffroy, V.A., Baida, N., Gardan, L., Izard, D., Lemanceau, P., Achouak, W. Palleroni, N.J., 2002. Siderophore typing, a powerful tool for the identification of fluorescent and nonfluorescent pseudomonads. Appl. Environ. Microbiol. 68, 2745-2753. https://doi.org/10.1128/AEM.68.6.2745-2753.2002.

Montero-Calasanz, M.C., Santamaría, C., Albareda, M., Daza, A., Duan, J. Glick, B.R. Camacho, M., 2013. Alternative rooting induction of semi-hardwood olive cuttings by several auxin-producing bacteria for organic agriculture systems. Spanish J. Agric. Res. 11, 146-154. https://doi.org/10.5424/sjar/2013111-2686.

Mustafa, S., Kabir, S., Shabbir, U., Batool, R., 2019. Plant growth promoting rhizobacteria in sustainable agriculture: from theoretical to pragmatic approach. Symbiosis https:// doi.org/10.1007/s13199-019-00602-w.

Nadal, P., García-Delgado, C., Hernández, D., López-Rayo, S., Lucena, J. 2012. Evaluation of Fe- $N, N^{\prime}$-Bis(2-hydroxybenzyl)ethylenediamine- $N, N^{\prime}$-diacetate $\left(\mathrm{HBED} / \mathrm{Fe}^{3}\right.$ ) as $\mathrm{Fe}$ carrier for soybean (Glycine max) plants grown in calcareous soil. Plant Soil 360, 349-362. https://doi.org/10.1007/s11104-012-1246-z.

Nagata, T. 2017. Effect of Pseudomonas fluorescens inoculation on the improvement of iron deficiency in tomato. Plant Root 11, 1-9. https://doi.org/10.3117/plantroot.11.1.

Niazi, A., Manzoor, S., Asari, S., Bejai, S., Meijer, J., Bongcam-Rudloff, E., 2014. Genome analysis of Bacillus amyloliquefaciens subsp. plantarum UCMB5113: a rhizobacterium that improves plant growth and stress management. PLoS One 9, e104651. https:// doi.org/10.1371/journal.pone.0104651.

Noreen, F., Noreen, S., 2014. Effect of different fertilizers on yield of wheat. J. Environ. Biol. 3, 2012-2015.

Ntougias, S., Zervakis, G.I., Ehaliotis, C., Kavroulakis, N., Papadopoulou, K.K., 2006. Ecophysiology and molecular phylogeny of bacteria isolated from alkaline two-phase olive mill wastes. Res. Microbiol. 157, 376-385. https://doi.org/10.1016/j. resmic.2005.09.010

Olanrewaju, O.S., Glick, B.R., Babalola, O.O., 2017. Mechanisms of action of plant growth promoting bacteria. World J. Microbiol. Biotechnol. 33, 197. https://doi.org/10.1007/ s11274-017-2364-9.

Omer, Z.S., Björkman, P.O., Nicander, B., Tillberg, E., Gerhardson, B., 2004. 5'Deoxyisopentenyladenosine and other cytokinins in culture filtrates of the bacterium Pantoea agglomerans. Physiol. Plant. 121, 439-447. https://doi.org/10.1111/j.13993054.2004.00337.x.
Ong, S.A., Peterson, T., Neilands, J.B., 1979. Agrobactin, a siderophore from Agrobacterium tumefaciens. J. Biol. Chem. 254, 1860-1865.

Opelt, K., Berg, C., Berg, G., 2007. The bryophyte genus Sphagnum is a reservoir for powerful and extraordinary antagonists and potentially facultative human pathogens. FEMS Microbiol. Ecol. 61, 38-53. https://doi.org/10.1111/j.1574-6941.2007.00323.x.

Oviedo, C., Rodríguez, J., 2003. EDTA: the chelating agent under environmental scrutiny. Quim Nova 26, 901-905. https://doi.org/10.1590/S0100-40422003000600020.

Owen, D., Williams, A.P., Griffith, G.W., Withers, P.J.A., 2015. Use of commercial bioinoculants to increase agricultural production through improved phosphrous acquisition. Appl. Soil Ecol. 86, 41-54. https://doi.org/10.1016/j.apsoil.2014.09.012.

Özen, A.I., Ussery, D.W., 2012. Defining the Pseudomonas genus: where do we draw the line with Azotobacter? Microb. Ecol. 63, 239-248. https://doi.org/10.1007/s00248011-9914-8.

Page, W.J., 1987. Iron-dependent production of hydroxamate by sodium-dependent Azotobacter chroococcum. Appl. Environ. Microbiol. 53, 1418-1424.

Page, W.J., Shivprasad, S., 1995. Iron binding to Azotobacter salinestris melanin, iron mobilization and uptake mediated by siderophores. Biometals 8, 59-64.

Page, W.J., Tigerstrom, M.V., 1988. Aminochelin, a catecholamine siderophore produced by Azotobacter vinelandii. Microbiology 134, 453-460. https://doi.org/10.1099/ 00221287-134-2-453.

Parte, A.C., 2018. LPSN - list of prokaryotic names with standing in nomenclature (bacterio.net), 20 years on. Int. J. Syst. Evol. Microbiol. 68, 1825-1829. https://doi. org/10.1099/ijsem.0.002786.

Peng, G., Wang, H., Zhang, G., Hou, W., Liu, Y., Wang, E.T., Tan, Z., 2006. Azospirillum melinis sp. nov., a group of diazotrophs isolated from tropical molasses grass. Int. J. Syst. Evol. Microbiol. 56, 1263-1271. https://doi.org/10.1099/ijs.0.64025-0.

Pereira, S.I.A., Castro, P.M.L., 2014. Diversity and characterization of culturable bacterial endophytes from Zea mays and their potential as plant growth-promoting agents in metal-degraded soils. Environ. Sci. Pollut. Res. 21, 14110-14123. https://doi.org/ 10.1007/s11356-014-3309-6.

Perrig, D., Boiero, M.L., Masciarelli, O.A., Penna, C., Ruiz, O.A., Cassán, F.D., Luna, M.V., 2007. Plant-growth-promoting compounds produced by two agronomically important strains of Azospirillum brasilense, and implications for inoculant formulation. Appl. Microbiol. Biotechnol. 75, 1143-1150. https://doi.org/10.1007/ s00253-007-0909-9.

Persmark, M., Pittman, P., Buyer, J.S., Schwyn, B., Gill, P.R., Neilands, J.B., 1993. Isolation and structure of rhizobactin 1021, a siderophore from the alfalfa symbiont Rhizobium meliloti 1021. J. Am. Chem. Soc. 115, 3950-3956. https://doi.org/10.1021/ ja00063a014.

Pham, V.T.K., Rediers, H., Ghequire, M.G.K., Nguyen, H.H., De Mot, R., Vanderleyden, J., Spaepen, S., 2017. The plant growth-promoting effect of the nitrogen-fixing endophyte Pseudomonas stutzeri A15. Arch. Microbiol. 199, 513-517. https://doi.org/ 10.1007/s00203-016-1332-3.

Philson, S.B., Llinas, M., 1982. Siderochromes from Pseudomonas fluorescens 1. Isolation and characterization. J. Biol. Chem. 257, 8081-8085.

Pierwola, A., Krupinski, T., Zalupski, P., Chiarelli, M., Castignetti, D., 2004. Degradation pathway and generation of monohydroxamic acids from the trihydroxamate siderophore deferrioxamine B. Appl. Environ. Microbiol. 70, 831-836. https://doi. org/10.1128/AEM.70.2.831-836.2004.

Piromyou, P., Noisangiam, R., Uchiyama, H., Tittabutr, P., Boonkerd, N., Teaumroong, N., 2013. Indigenous microbial community structure in rhizosphere of Chinese kale as affected by plant drowth-promoting rhizobacteria inoculation. Pedosphere 23, 577-592. https://doi.org/10.1016/S1002-0160(13)60051-X

Ponmurugan, K., Sankaranarayanan, A., Al-Dhabi, N.A., 2012. Biological activities of plant growth promoting Azotobacter sp. isolated from vegetable crops rhizosphere soils. J. Pure Appl. Microbiol. 66, 1689-1698.

Possiede, Y.M. Gabardo, J. Kava-Cordeiro, V. Galli-Terasawa, LV. Azevedo, J.L, Glienke, C., 2009. Fungicide resistance and genetic variability in plant pathogenic strains of Guignardia citricarpa. Brazilian J. Microbiol. 40, 308-313. https://doi.org/10.1590/ S1517-83822009000200018.

Pourbabaee, A.A., Shoaibi, F., Emami, S., Alikhani, H.A., 2018. The potential contribution of siderophore producing bacteria on growth and Fe ion concentration of sunflower (Helianthus annuus L.) under water stress. J. Plant Nutr. 41, 619-626. https://doi. org/10.1080/01904167.2017.1406112.

Powell, P.E., Szaniszlo, P.J., Cline, G.R., Reid, C.P.P., 1982. Hydroxamate siderophores in the iron nutrition of plants. J. Plant Nutr. 5, 653-673. https://doi.org/10.1080/ 01904168209362994

Probanza, A., Lucas García, J.A., Ruiz Palomino, M., Ramos, B., Gutiérrez Mañero, FJ., 2002. Pinus pinea L. seedling growth and bacterial rhizosphere structure after inoculation with PGPR Bacillus (B. licheniformis CECT 5106 and B. pumilus CECT 5105). Appl. Soil Ecol. 20, 75-84. https://doi.org/10.1016/S0929-1393(02)00007-0.

Public Health Agency of Canada, 2018. Canadian pathogen safety data sheets. [WWW Document]. URL. https://www.canada.ca/en/public-health/services/laboratory-biosafety-biosecurity/pathogen-safety-data-sheets-risk-assessment.html, Accessed date: 5 December 2018

Rashid, S., Charles, T.C., Glick, B.R., 2012. Isolation and characterization of new plant growth-promoting bacterial endophytes. Appl. Soil Ecol. 61, 217-224. https://doi. org/10.1016/j.apsoil.2011.09.011.

Rasouli-Sadaghiani, M., Malakouti, M.J., Khavazi, K., Miransari, M., 2014. Siderophore efficacy of fluorescent pseudomonades affecting labeled iron $\left({ }^{59} \mathrm{fe}\right)$ uptake by wheat (Triticum aestivum 1.) genotypes differing in Fe efficiency. Use of Microbes for the Alleviation of Soil Stresses: Volume 2: Alleviation of Soil Stress by Pgpr and Mycorrhizal Fungi. Springer New York, New York, NY, pp. 121-132 https://doi.org/10.1007/9781-4939-0721-2_7

Ringel, M.T., Brüser, T., 2018. The biosynthesis of pyoverdines. Microb. Cell 5, 424-437. https://doi.org/10.15698/mic2018.10.649. 
Rodriguez, H., Gonzalez, T., Goire, I., Bashan, Y., 2004. Gluconic acid production and phosphate solubilization by the plant growth-promoting bacterium Azospirillum spp. Naturwissenschaften 91, 552-555. https://doi.org/10.1007/s00114-004-0566-0.

Romero-Perdomo, F., Abril, J., Camelo, M., Moreno-Galván, A., Pastrana, I., Rojas-Tapias, D., Bonilla, R., 2017. Azotobacter chroococcum as a potentially useful bacterial biofertilizer for cotton (Gossypium hirsutum): effect in reducing $\mathrm{N}$ fertilization. Rev. Argent. Microbiol. 49, 377-383. https://doi.org/10.1016/j.ram.2017.04.006.

Rosenberg, D.R., Maurice, P.A., 2003. Siderophore adsorption to and dissolution of kaolinite at $\mathrm{pH} 3$ to 7 and $22^{\circ} \mathrm{C}$. Geochim. Cosmochim. Acta 67, 223-229. https://doi.org/ 10.1016/S0016-7037(02)01082-7.

Sabaté, D.C., Pérez Brandan, C., Petroselli, G., Erra-Balsells, R., Audisio, M.C., 2017. Decrease in the incidence of charcoal root rot in common bean (Phaseolus vulgaris L.) by Bacillus amyloliquefaciens B14, a strain with PGPR properties. Biol. Control 113, 1-8. https://doi.org/10.1016/j.biocontrol.2017.06.008.

Sah, S., Singh, R., 2015. Siderophore: structural and functional characterisation - a comprehensive review. Agric 61. https://doi.org/10.1515/agri-2015-0015.

Saha, R., Saha, N., Donofrio, R.S., Bestervelt, L.L., 2013. Microbial siderophores: a mini review. J. Basic Microbiol. 53, 303-317. https://doi.org/10.1002/jobm.201100552.

Saha, M., Sarkar, S., Sarkar, B., Sharma, B.K., Bhattacharjee, S., Tribedi, P., 2016. Microbial siderophores and their potential applications: a review. Environ. Sci. Pollut. Res. Int. 23, 3984-3999. https://doi.org/10.1007/s11356-015-4294-0.

Sahoo, R.K., Ansari, M.W., Dangar, T.K., Mohanty, S., Tuteja, N., 2013. Phenotypic and molecular characterisation of efficient nitrogen-fixing Azotobacter strains from rice fields for crop improvement. Protoplasma 251, 511-523. https://doi.org/10.1007/s00709013-0547-2.

Sahoo, R.K., Ansari, M.W., Pradhan, M., Dangar, T.K., Mohanty, S., Tuteja, N., 2014. Phenotypic and molecular characterization of native Azospirillum strains from rice fields to improve crop productivity. Protoplasma 251, 943-953. https://doi.org/10.1007/ s00709-013-0607-7.

Sai Prasad, J., Subhash Reddy, R., Sarvanp, B.H., Naveen Kumar, R., Narayan Reddy, P., 2014. Isolation and biochemical characterization of Rhizobium for plant growth promotion and antagonistic activities and compatibility with commonly used pesticides. Pollut. Res. 33, 379-387.

Sanchis, V., Bourguet, D., 2008. Bacillus thuringiensis: Applications in agriculture and insect resistance management. A review. In: Lichtfouse, E., Navarrete, M., Debaeke, P., Véronique, S., Alberola, C. (Eds.), Agronomy for Sustainable Development. Springer Netherlands, Dordrecht, pp. 11-20 https://doi.org/10.1051/agro:2007054.

Sandhya, V., Ali, S.Z., Grover, M., Reddy, G., Venkateswarlu, B., 2010. Effect of plant growth promoting Pseudomonas spp. on compatible solutes, antioxidant status and plant growth of maize under drought stress. Plant Growth Regul. 62, 21-30. https://doi. org/10.1007/s10725-010-9479-4.

Sandy, M., Butler, A., 2011. Chrysobactin siderophores produced by Dickeya chrysanthemi EC16. J. Nat. Prod. 74, 1207-1212. https://doi.org/10.1021/np200126z.

Santos, S., Neto, I.F.F., Machado, M.D., Soares, H.M.V.M., Soares, E.V., 2014. Siderophore production by Bacillus megaterium: effect of growth phase and cultural conditions. Appl. Biochem. Biotechnol. 172, 549-560. https://doi.org/10.1007/s12010-0130562-y.

Saraf, M., Pandya, U., Thakkar, A., 2014. Role of allelochemicals in plant growth promoting rhizobacteria for biocontrol of phytopathogens. Microbiol. Res. 169, 18-29. https:// doi.org/10.1016/j.micres.2013.08.009.

Sattar, A., Naveed, M., Ali, M., Zahir, Z.A., Nadeem, S.M., Yaseen, M., Meena, V.S., Farooq, M., Singh, R., Rahman, M., Meena, H.N., 2019. Perspectives of potassium solubilizing microbes in sustainable food production system: a review. Appl. Soil Ecol. 133, 146-159. https://doi.org/10.1016/j.apsoil.2018.09.012.

Saxena, B., Vithlani, L., Modi, V.V., 1989. Siderophore-mediated transport of molybdenum in Azospirillum lipoferum strain D-2. Curr. Microbiol. 19, 291-295. https://doi.org/ 10.1007/BF01570103.

Sayyed, R.Z., Badgujar, M.D., Sonawane, H.M., Mhaske, M.M., Chincholkar, S.B., 2005. Production of microbial iron chelators (siderophores) by fluorescent pseudomonads. Indian J. Biotechnol. 4, 484-490.

Schütze, E., Ahmed, E., Voit, A., Klose, M., Greyer, M., Svatoš, A., Merten, D., Roth, M., Holmström, S.J.M., Kothe, E., 2014. Siderophore production by streptomycetesstability and alteration of ferrihydroxamates in heavy metal-contaminated soil. Environ. Sci. Pollut. Res. Int. https://doi.org/10.1007/s11356-014-3842-3.

Shah, S., Karkhanis, V., Desai, A., 1992. Isolation and characterization of siderophore, with antimicrobial activity, from Azospirillum lipoferum M. Curr. Microbiol. 25, 347-351. https://doi.org/10.1007/BF01577233.

Shailesh, K.S., Ashutosh, K.R., Madhu, B.T., Rajeshwar, P.S., Ashok, K., 2011. Rhizosphere of rice plants harbor bacteria with multiple plant growth promoting features. African J. Biotechnol. 10, 8296-8305. https://doi.org/10.5897/AJB11.602.

Sharma, D., Das, M., 2010. In vitro studies of antagonistic behaviour of Rhizobium strain against phytopathogenic fungi. Natl. Acad. Sci. Lett. 33, 17-20.

Sheff, B., 2003. Bacillus anthracis. Nursing (Lond) 33, 78. https://doi.org/10.1002/ ardp. 18812180460

Shenker, M., Chen, Y., 2005. Increasing iron availability to crops: fertilizers, organofertilizers, and biological approaches. Soil Sci. Plant Nutr. 51, 1-17. https://doi.org/ 10.1111/j.1747-0765.2005.tb00001.x.

Shirinbayan, S., Khosravi, H., Malakouti, M.J., 2019. Alleviation of drought stress in maize (Zea mays) by inoculation with Azotobacter strains isolated from semiarid regions. Appl. Soil Ecol. 133, 138-145. https://doi.org/10.1016/j. apsoil.2018.09.015.

Siddiqui, Z.A., Baghel, G., Akhtar, M.S., 2007. Biocontrol of Meloidogyne javanica by Rhizobium and plant growth-promoting rhizobacteria on lentil. World J. Microbiol. Biotechnol. 23, 435-441. https://doi.org/10.1007/s11274-006-9244-Z.

Siebner-Freibach, H., Hadar, Y., Yariv, S., Lapides, I., Chen, Y., 2006. Thermospectroscopic study of the adsorption mechanism of the hydroxamic siderophore ferrioxamine $B$ by calcium montmorillonite. J. Agric. Food Chem. 54, 1399-1408. https://doi.org/ 10.1021/jf051924e.

Simanova, A.A., Persson, P., Loring, J.S., 2010. Evidence for ligand hydrolysis and Fe(III) reduction in the dissolution of goethite by desferrioxamine-B. Geochim. Cosmochim. Acta 74, 6706-6720. https://doi.org/10.1016/j.gca.2010.08.037.

Sitbon, F., Hennion, S., Sundberg, B., Little, C.H., Olsson, O., Sandberg, G., 1992. Transgenic tobacco plants coexpressing the Agrobacterium tumefaciens iaaM and iaaH genes display altered growth and indoleacetic acid metabolism. Plant Physiol. 99, 1062-1069. https://doi.org/10.1104/pp.99.3.1062.

Smith, M.J., Neilands, J.B., 1984. Rhizobactin, a siderophore from Rhizobium meliloti. J. Plant Nutr. 7, 449-458. https://doi.org/10.1080/01904168409363211.

Smith, M.J., Shoolery, J.N., Schwyn, B., Holden, I., Neilands, J.B., 1985. Rhizobactin, a structurally novel siderophore from Rhizobium meliloti. J. Am. Chem. Soc. 107, 1739-1743. https://doi.org/10.1021/ja00292a047.

Smits, T.H.M., Rezzonico, F., Pelludat, C., Goesmann, A., Frey, J.E., Duffy, B., 2010. Genomic and phenotypic characterization of a nonpigmented variant of Pantoea vagans biocontrol strain C9-1 lacking the 530-kb megaplasmid pPag3. FEMS Microbiol. Lett 308, 48-54. https://doi.org/10.1111/j.1574-6968.2010.01994.x.

Somasegaran, P., Hoben, H.J., 1994. Handbook for Rhizobia. Springer New York, New York NY https://doi.org/10.1007/978-1-4613-8375-8.

Soutar, C.D., Stavrinides, J., 2018. The evolution of three siderophore biosynthetic clusters in environmental and host-associating strains of Pantoea. Mol. Gen. Genomics. 293, 1453-1467. https://doi.org/10.1007/s00438-018-1477-7.

de Souza, E.M., Bassani, V.L., Sperotto, R.A., Granada, C.E., 2016. Inoculation of new rhizobial isolates improve nutrient uptake and growth of bean (Phaseolus vulgaris) and arugula (Eruca sativa). J. Sci. Food Agric. 96, 3446-3453. https://doi.org/10.1002/ jsfa.7527.

Spaepen, S., Vanderleyden, J., Remans, R., 2007. Indole-3-acetic acid in microbial and microorganism-plant signaling. FEMS Microbiol. Rev. 31, 425-448. https://doi.org/ 10.1111/j.1574-6976.2007.00072.x.

Steenhoudt, O., Vanderleyden, J., 2000. Azospirillum, a free-living nitrogen-fixing bacterium closely associated with grasses: genetic, biochemical and ecological aspects. FEMS Microbiol. Rev. 24, 487-506. https://doi.org/10.1111/j.1574-6976.2000. tb00552.x.

Storey, E.P., Boghozian, R., Little, J.L., Lowman, D.W., Chakraborty, R., 2006. Characterization of 'Schizokinen'; a dihydroxamate-type siderophore produced by Rhizobium leguminosarum IARI 917. BioMetals 19, 637-649. https://doi.org/10.1007/s10534006-9001-7

Subramanian, J., Satyan, K., 2014. Isolation and selection of fluorescent pseudomonads based on multiple plant growth promotion traits and siderotyping. Chil. J. Agric. Res. 74, 319-325. https://doi.org/10.4067/S0718-58392014000300010.

Sulbarán, M., Pérez, E., Ball, M.M., Bahsas, A., Yarzábal, L.A., 2009. Characterization of the mineral phosphate-solubilizing activity of Pantoea aglomerans MMB051 isolated from an iron-rich soil in southeastern Venezuela (Bolívar State). Curr. Microbiol. 58, 378-383. https://doi.org/10.1007/s00284-008-9327-1.

Sulochana, M.B., Jayachandra, S.Y., Kumar, S.A., Parameshwar, A.B., Reddy, K.M., Dayanand, A., 2014. Siderophore as a potential plant growth-promoting agent produced by Pseudomonas aeruginosa JAS-25. Appl. Biochem. Biotechnol. 174, 297-308. https://doi.org/10.1007/s12010-014-1039-3.

Suneja, S. Lakshminarayana, K., Narula, N. 1994. Optimization of cultural conditions for hydroxamate type of siderophore production by Azotobacter chroococcum. Microbiol. Res. 149, 385-390. https://doi.org/10.1016/S0944-5013(11)80086-8.

Suneja, S., Narula, N., Anand, R.C., Lakshminarayana, K., 1996. Relationship of Azotobacter chrooccum siderophores with nitrogen fixation. Folia Microbiol. (Praha). 41, 154-158. https://doi.org/10.1007/BF02814692.

Tabassum, B., Khan, A., Tariq, M., Ramzan, M., Iqbal Khan, M.S., Shahid, N., Aaliya, K., 2017. Bottlenecks in commercialisation and future prospects of PGPR. Appl. Soil Ecol. 121, 102-117. https://doi.org/10.1016/j.apsoil.2017.09.030.

Tan, K.Z., Radziah, O., Halimi, M.S., Khairuddin, A.R., Habib, S.H., Shamsuddin, Z.H., 2014. Isolation and characterization of rhizobia and plant growth-promoting rhizobacteria and their effects on growth of rice seedlings. Am. J. Agric. Biol. Sci. 9, 342-360. https:// doi.org/10.3844/ajabssp.2014.342.360.

Teintze, M., Leong, J., 1981. Structure of pseudobactin A, a second siderophore from plant growth promoting Pseudomonas B10. Biochemistry 20, 6457-6462. https://doi.org/ 10.1021/bi00525a026.

Teintze, M., Hossain, M.B., Barnes, C.L., Leong, J., van der Helm, D., 1981. Structure of ferric pseudobactin, a siderophore from a plant growth promoting Pseudomonas. Biochemistry 20, 6446-6457. https://doi.org/10.1021/bi00525a026.

Tien, T.M., Gaskins, M.H., Hubbell, D.H., 1979. Plant growth substances produced by Azospirillum brasilense and their effect on the growth of pearl millet (Pennisetum americanum L.). Appl. Environ. Microbiol. 37, 1016-1024.

Timmusk, S., Behers, L., Muthoni, J., Muraya, A., Aronsson, A.-C., 2017. Perspectives and challenges of microbial application for crop improvement. Front. Plant Sci. 8. https://doi.org/10.3389/fpls.2017.00049.

Torres, L., Perez-Ortin, J.E., Tordera, V., Beltran, J.P., 1986. Isolation and characterization of an Fe(III)-chelating compound produced by Pseudomonas syringae. Appl. Environ. Microbiol. 52, 157-160.

Torres-Rubio, M.G., Valencia-Plata, S.A., Bernal-Castillo, J., Martínez-Nieto, P., 2000. Isolation of enterobacteria, Azotobacter sp. and Pseudomonas sp., producers of indole-3 acetic acid and siderophores, from Colombian rice rhizosphere. Rev. Latinoam. Microbiol. 42, 171-176.

Tortora, M.L., Díaz-Ricci, J.C., Pedraza, R.O., 2011. Azospirillum brasilense siderophores with antifungal activity against Colletotrichum acutatum. Arch. Microbiol. 193, 275-286. https://doi.org/10.1007/s00203-010-0672-7.

Trifi, H., Ben Salem, I., Kolsi Benzina, N., Fourati, A., Costa, M.C. Achouak, W., Sghaier, H. Saidi, M., 2017. Effectiveness of the plant growth-promoting rhizobacterium Pantoea 
sp. BRM17 in enhancing Brassica napus growth in phosphogypsum-amended soil. Pedosphere 27, 1-14. https://doi.org/10.1016/S1002-0160(17)60454-5.

Turnbull, P.C.B., 1996. Bacillus. In: Barron, S. (Ed.), Barron's Medical Microbiology. University of Texas Medical Branch, Galveston.

Villa, J.A., Ray, E.E., Barney, B.M., 2014. Azotobacter vinelandii siderophore can provide nitrogen to support the culture of the green algae neochloris oleoabundans and scenedesmus sp. BA032. FEMS Microbiol. Lett. 351, 70-77. https://doi.org/10.1111/ 1574-6968.12347.

Viruel, E., Lucca, M.E., Siñeriz, F., 2011. Plant growth promotion traits of phosphobacteria isolated from Puna, Argentina. Arch. Microbiol. 193, 489-496. https://doi.org/ 10.1007/s00203-011-0692-y.

Visca, P., Imperi, F., Lamont, I.L., 2007. Pyoverdine siderophores: from biogenesis to biosignificance. Trends Microbiol. 15, 22-30. https://doi.org/10.1016/j.tim.2006.11.004.

Voets, J.P., Dedeken, M., 1966. A physiological approach to the classification of the genus Azotobacter. In: Virology, Ivanovski Institute of (Ed.), International Congress for Microbiology. Elsevier, pp. 103-108 https://doi.org/10.1016/B978-0-08-012251-9.50016-5.

Walterson, A.M., Stavrinides, J., 2015. Pantoea: insights into a highly versatile and diverse genus within the Enterobacteriaceae. FEMS Microbiol. Rev. 39, 968-984. https://doi. org/10.1093/femsre/fuv027.

Wendenbaum, S., Demange, P., Dell, A., Meyer, J.M., Abdallah, M.A., 1983. The structure of pyoverdine Pa, the siderophore of Pseudomonas aeruginosa. Tetrahedron Lett. 24, 4877-4880. https://doi.org/10.1016/S0040-4039(00)94031-0.

Wilson, M.K., Abergel, R.J., Raymond, K.N., Arceneaux, J.E.L., Byers, B.R., 2006. Siderophores of Bacillus anthracis, Bacillus cereus, and Bacillus thuringiensis. Biochem. Biophys. Res. Commun. 348, 320-325. https://doi.org/10.1016/j.bbrc.2006.07.055.

Woo, S.L., Lorito, M., 2007. Exploiting the interactions between fungal antagonists, pathogens and the plant for biocontrol. NATO Secur. through Sci. Ser. A Chem. Biol., 107-130 https://doi.org/10.1007/978-1-4020-5799-1-6.
Worldometers, 2018. Current world population [WWW document]. URL. http://www. worldometers.info/world-population/, Accessed date: 4 December 2018.

Wright, W., Little, J., Liu, F., Chakraborty, R., 2013. Isolation and structural identification of the trihydroxamate siderophore vicibactin and its degradative products from Rhizobium leguminosarum ATCC 14479 bv. trifolii. BioMetals 26, 271-283. https://doi.org/ 10.1007/s10534-013-9609-3

Wu, B., Wang, X., Yang, L., Yang, H., Zeng, H., Qiu, Y., Wang, C., Yu, J., Li, J., Xu, D., He, Z., Chen, S., 2016. Effects of Bacillus amyloliquefaciens ZM9 on bacterial wilt and rhizosphere microbial communities of tobacco. Appl. Soil Ecol. 103, 1-12. https://doi.org/ 10.1016/j.apsoil.2016.03.002.

Xie, J., Shu, P., Strobel, G., Chen, J., Wei, J., Xiang, Z., Zhou, Z., 2017. Pantoea agglomerans SWg2 colonizes mulberry tissues, promotes disease protection and seedling growth. Biol. Control 113, 9-17. https://doi.org/10.1016/J.BIOCONTROL.2017.06.010.

Xing, Y.X., Wei, C.Y., Mo, Y., Yang, L.T., Huang, S.L., Li, Y.R., 2016. Nitrogen-fixing and plant growth-promoting ability of two endophytic bacterial strains isolated from sugarcane stalks. Sugar Tech 18, 373-379. https://doi.org/10.1007/s12355-015-0397-7.

Yang, G.Q., Chen, M., Yu, Z., Lu, Q., Zhou, S.G., 2013. Bacillus composti sp. nov. and Bacillus thermophilus sp. nov., two thermophilic, Fe(III)-reducing bacteria isolated from compost. Int. J. Syst. Evol. Microbiol. 63, 3030-3036. https://doi.org/10.1099/ijs.0.049106-0.

Zhang, W., 2018. Global pesticide use: profile, trend, cost/benefit and more. Proc. Int. Acad. Ecol. Environ. Sci. 8, 1-27.

Zhang, W., Zhang, Y., Wang, X., Ding, F., Fu, Y., Zhao, J., Song, W., Opiyo, OJ., Zhang, F., Chen, X., 2017. Siderophores in clinical isolates of Klebsiella pneumoniae promote ciprofloxacin resistance by inhibiting the oxidative stress. Biochem. Biophys. Res. Commun. 491, 855-861. https://doi.org/10.1016/j.bbrc.2017.04.108. 